Review

\title{
Cell-iree Circulating miRNA Biomarkers in Cancer
}

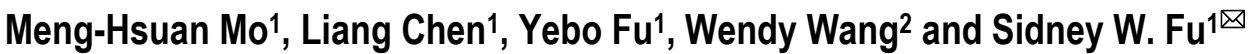 \\ 1. Department of Medicine, Division of Genomic Medicine, and Department of Microbiology, Immunology and Tropical \\ Medicine, The George Washington University School of Medicine and Health Sciences, Washington, DC, USA; \\ 2. Cancer Biomarkers Research Group, Division of Cancer Prevention, NIH/NCI, Bethesda, MD, USA.
}

Corresponding author: Sidney W. Fu, M.D., Ph.D. Professor. Department of Medicine, Division of Genomic Medicine, Department of Microbiology, Immunology and Tropical Medicine, The George Washington University Medical Center, 2300 I Street, N.W. Room 443B, Washington, DC 20037. Email: sfu@gwu.edu Tel: 202-994-4767 Fax: 202-994-8924.

(c) Ivyspring International Publisher. This is an open-access article distributed under the terms of the Creative Commons License (http://creativecommons.org/ licenses/by-nc-nd/3.0/). Reproduction is permitted for personal, noncommercial use, provided that the article is in whole, unmodified, and properly cited.

Received: 2012.07.23; Accepted: 2012.10.10; Published: 2012.10.13

\begin{abstract}
Considerable attention and an enormous amount of resources have been dedicated to cancer biomarker discovery and validation. However, there are still a limited number of useful biomarkers available for clinical use. An ideal biomarker should be easily assayed with minimally invasive medical procedures but possess high sensitivity and specificity. Commonly used circulating biomarkers are proteins in serum, most of which require labor-intensive analysis hindered by low sensitivity in early tumor detection. Since the deregulation of microRNA (miRNA) is associated with cancer development and progression, profiling of circulating miRNAs has been used in a number of studies to identify novel minimally invasive miRNA biomarkers. In this review, we discuss the origin of the circulating cell-free miRNAs and their carriers in blood. We summarize the clinical use and function of potentially promising miRNA biomarkers in a variety of different cancers, along with their downstream target genes in tumor initiation and development. Additionally, we analyze some technical challenges in applying miRNA biomarkers to clinical practice.
\end{abstract}

Key words: serum, cancer, miRNA, biomarker.

\section{Background}

miRNAs are a class of small (18-24 nt) non-coding regulatory RNAs that are involved in regulating gene expression at the post-transcriptional level. According to miRBase Release 18 (November 2011), 1,898 unique mature human miRNAs have been identified [1] [2]. These RNA molecules regulate numerous biological processes [3] [4], potentially up to one third of all protein-coding genes based on computational predictions [5]. Primary miRNA (pri-miRNA) is cleaved by endonuclease RNase III Dorsha in the nucleus, releasing the stem-loop pre-miRNA [6]. Then the pre-miRNA is exported into the cytoplasm and cleaved by endonuclease Dicer before becoming mature miRNA, which is integrated into the RNA-induced silencing complex (RISC) to regulate target gene expression [7, 8]. Perfectly or imperfectly base pairing the $3^{\prime}$ UTR of the target mRNA with the $5^{\prime}$ end of miRNA causes genomic instability and transcriptional degradation, as well as translational repression [6, 9-11]. However, it is also reported that miRNA can induce target gene overexpression [12]. The miRNA genome is often located at fragile genomic sites which are closely related to cancer. Their expression is deregulated due to genomic instabilities $[13,14]$. We showed that the expression of the TAR miRNA protects infected cells from apoptosis and acts by down-regulating cellular genes involved in apoptosis [15]. The role of miRNAs 
in cancer was first suspected when it was observed in C. elegans and Drosophila that miRNAs controlled aspects of cell proliferation and apoptosis [16] [17]. Expression of various miRNAs has been reported to be differentially altered across a variety of tumor types, suggesting their direct involvement in oncogenesis [18] [19] [20]. Deregulated miRNA expression profiles were identified in many human cancers using miRNA profiling techniques. miRNAs are associated with embryogenesis and stem cell maintenance in mammals [21], hematopoietic stem cell differentiation [22], and cancers [23] [24] [25]. Many studies show that miRNA expression appears to be deregulated in cancer $[26,27]$.

\section{Origin of the circulating miRNAs and their carriers}

MicroRNAs (miRNAs), a novel class of gene regulators, have recently been studied as biomarkers in peripheral circulation for cancer detection. However, the origin and value of these miRNAs have yet to be elucidated. It is widely believed that the circulating miRNAs might not only come from circulating tumor cells $[28,29]$, but also be released into the blood stream directly via blood cells [30] or other tissue cells affected by disease [31]. It is becoming clearer that the majority circulating miRNAs are chaperoned by various carriers, such as exosomes, Ago2, HDL, etc.[32], as carrier-free miRNAs will be degraded by RNase digestion and other environmental factors [33-35]. However, it is still debatable whether or not miRNAs are highly enriched in exosomes or in Arg-2 protein complexes [36, 37], which may explain the differences of miRNA abundance between isolating from whole blood and from plasma or serum.

Heneghan et al. claimed that a whole blood sample is preferable to serum and plasma for detecting miRNAs in the circulation since the concentration of miRNAs extracted from whole blood is higher than from serum or plasma [29]. This raises a basic concern toward the origin of miRNAs in circulation. By sequencing miRNAs in serum and blood cells of healthy subjects, Chen et al. noticed that most miRNAs detected in serum were almost the same type as in blood cells [31], implying that serum miRNAs are not only derived from primary disease sites, but also from circulating blood cells [28]. Based on those observations, we believe using whole blood as the starting material may increase the background signal noise in terms of screening for disease-derived miRNAs. In the future, for any circulating miRNA research, differentiating between cellular miRNAs and cell-free miRNAs is crucial.
It is known that signatures of plasma/serum miRNAs can reflect correlations to physiological or disease conditions. LaConti et al. observed a correlation of miRNA deregulations between tissue and serum in both the Kras ${ }^{\mathrm{G} 12 \mathrm{D}}$ transgenic animals and the prostate cancer patients [38]. On the other hand, several studies demonstrated that circulating oncogenic miRNA levels declined after tumor resection, such as miR-21 in esophageal squamous cell carcinoma (ESCC) [39], miR-31 in patients with oral squamous cell carcinoma (OSCC) [40], mir-29a and mir-92 in colorectal cancer CRC [41], miR-21 and miR-106b in gastric cancer [42], and miRNA-195 and let-7a in breast cancer[29]. Inversely, the levels of tumor-suppressor miRNAs were increased, such as miR-92a/ miR638 ratio in hepatocellular carcinoma (HCC) [43]. The alteration of miRNA expression in postoperative samples, compared to preoperative ones, robustly supported the notion that specific circulating miRNAs were from tumor cells. Furthermore, in a xenograft mice system, relatively elevated levels of miR-629 and miR-660 were detected in the plasma of mice xenografted with $22 \mathrm{Rv} 1$ cells, as compared to those of a control group [44]. Both miR-629 and miR-660 are expressed in $22 \mathrm{Rv} 1$ human prostate cancer cells and are absent of murine homologs. Taken together, this evidence might substantiate the claim that circulating miRNAs could be directly derived from tumor tissues, and that the alternation of miRNAs might directly reflect the biological activity of cancers.

Exosomes. Bearing the possibility that miRNAs secreted from tissue could be inferred by the miRNAs from blood cells in the circulating environment, researchers are trying to find an alternative by proposing exosomes $(40-100 \mathrm{~nm})$ as carriers of the circulating miRNAs released by exocytosis. This model is supported by the detection of exosomes associated with miRNAs [45-48] and vesicle encapsulated miRNAs in serum and plasma [34, 49-51]. Exosomes are small (50-90 nm) lipoprotein-membranous vesicles of endocytic origin, which is the fusion of multivesicular bodies (MVB) with plasma membranes secreted into extracellular space. Exosomes mediate cell-cell communications via ligand-receptor interaction and transport intracellular components, including delivering miRNAs in exosomes to recipient cells by fusion or endocytosis [52]. A variety of cells are capable of releasing exosomes, including reticulocytes [53], dendritic cells [54], B cells [55], T cells [56], mast cells [57], epithelial cells [58] and tumor cells [52, 59]. Some believe that exosomal miRNAs are secreted by a ceramide-dependent secretory mechanism [60]. Kosaka et al. demonstrated that over-expression of nSMase2, the rate-limiting enzyme of ceramide bio- 
synthesis, stimulated the secretion of exosomes as well as an abundance of extracellular miRNA [60]. For tumor growth and progression, these reports raised the possibility that tumor-derived exosomal miRNAs affect the surrounding cells through silencing tumor suppressing gene expression [61]. On the other hand, the inhibition of cell growth could be induced by releasing tumor suppressor miRNAs [60].

Taylor et al. first showed the presence of tumor-derived exosomes in the circulation of ovarian cancer patients [62]. They subsequently demonstrated that tumor-derived exosomes in circulation could be isolated from other normal exosomes by applying specific magnetic beads linked with a tumor-associated antibody, e.g. EpCAM, CD24 [63, 64]. By enriching tumor-derived exosomal miRNAs from other cellular miRNAs, they observed a noteworthy correlation between miRNAs and ovarian tumor samples. The similarity between circulating tumor-derived exosomal miRNAs and tissue miRNAs was also observed in paired tissue and plasma samples from patients with lung cancer [65]. However, marker proteins that allow for the separation of tumor-derived exosomes from normal vesicles are less defined.

HDL \& LDL. Besides exosomes, Vickers et al. found that high density lipoprotein (HDL) and light density lipoprotein (LDL) have the capability to carry and deliver miRNAs in plasma to distant recipient cells [66]. Furthermore, certain miRNAs were demonstrated to be exclusively encapsulated in either HDL or exosomes. These findings strengthen the vesicle carrier model by introducing more microvesicles as miRNA carriers. However, this also raises additional questions. For example, do cells choose specific carriers for different miRNAs depending on particular bio-functions [67], regulated by different up-taking pathways, such as endocytosis[68, 69] or membrane fusion[70, 71]?

Ago2. Nevertheless, the vesicle carrier model itself may not be the predominant mechanism for tissue secreted miRNAs. Some researchers surprisingly found that the majority of circulating miRNAs are co-fractionated with protein complexes rather than with microvesicles in both cultured cells and human plasma [33, 36]. They observed that most of the miRNAs completely passed through the $0.22 \mu \mathrm{m}$ filter but remained in the supernatant after ultracentrifugation at $110,000 \mathrm{~g}$, indicating most of the circulating miRNAs are independent of exosomes or microvesicles. Furthermore, Western blotting analysis revealed that the circulating miRNAs are co-immunoprecipitated with anti-Ago2 antibody in a detergent free environment [72]. This study showed that extracellular miRNAs are predominantly associated with the Ago2 protein ( 96kDa).

\section{Stability of the circulating miRNAs}

Circulating miRNAs can be readily detected in serum [73], plasma or whole blood [29]. Using Solexa sequencing technology, Chen et al. detected a great amount of small RNAs, 21-23nt length in both serum and whole blood samples from normal individuals, as well as patients with colorectal, non-small cell lung cancer and diabetes [31]. Another study confirmed the presence of small RNAs (18-24 nt) in plasma from the total RNA extracted from human plasma using radioactive labeling method [44]. Followed by cloning and sequencing of those small RNAs, over $93 \%$ of the sequences matched known miRNAs, and thus further confirmed that the majority of small RNAs isolated from plasma were indeed miRNAs. In addition, some randomly selected miRNAs were found to be expressed consistently in both serum and plasma samples from humans, as well as in other species, such as rats, mice, claves, bovine fetuses and horses [31].

MiRNAs are also notably stable in serum and plasma samples [29-31, 44, 73]. Chen et al. found that isolated serum miRNAs can survive the treatment of RNase A, compared to other endogenous RNAs such as 18s rRNA, 28s rRNA, GAPDH, $\beta$-actin and U6 [31]. Most serum miRNAs maintain considerable expression levels after 3 hours or overnight RNase A treatment; however large RNAs were degraded following 3 hours of RNase A treatment. Furthermore, repeat freeze-thawing cycles [31, 73] and low/ high $\mathrm{pH}$ solution [31] treatments did not affect serum miRNAs. Similarly, plasma miRNAs could remain stable in room temperature for 24 hours and eight freeze-thaw cycles; however, synthetic miRNAs were rapidly degraded in plasma [44]. This indicates that the endogenous plasma miRNAs in RNase-enriched circulating system exist in a form that is resistant to plasma RNase activity.

\section{Circulating miRNAs as cancer biomarkers}

Cancer biomarkers are used for early detection, prognosis $[29,74]$ and therapeutic guidance [29, 31, 74]. An ideal biomarker should be highly specific and sensitive with a high predictive value, which can be detected in a rapid and simple, yet accurate and inexpensive fashion [28, 73]. Here we summarize the use of individual miRNAs as blood-based biomarkers and their potential biological functions in circulation.

miR-1. miR-1 in serum was found differentially expressed in cancers, up-regulated in gastric cancer patients [75] and down-regulated in non-small-cell lung cancer (NSCLC) [76], as well as in primary hu- 
man lung tumor tissues and cell lines [77]. Ectopic expression of miR-1 decreased migration and invasion of the A549 lung cell line and restrained cell proliferation, clonogenic survival, and anchorage-independent growth in the H1229 lung cell line. MET (hepatocyte growth factor receptor), a receptor-type tyrosine kinase, and Pim-1, a Ser/Thr kinase inducing tumorigenesis by promoting cell cycle progression and inhibiting apoptosis, are direct targets of miR-1 in lung cells[77]. Additionally, in hepatocellular carcinoma[78], rhabdomyosarcoma [79], head and neck squamous cell carcinoma (HNSCC) [80] and bladder cancer [81], a relatively low miR-1 expression level was observed, consistent with the effect of ectopically expressed miR-1 on tumor cell growth. Several target genes of miR-1, including MET [78], FOXP1 [78], c-Met [79] and transgelin 2 (TAGLN2) [80, 81], were validated in these cancers.

miR-10b. Compared to healthy subjects, whole blood miR-10b was down-regulated in colon and renal cancers as well as melanoma, but not in breast and prostate cancers [82]. However, Heneghan et al. revealed that circulating miR-10b was higher in ER (estrogen receptor)-negative patients than in ER-positive ones, but it cannot discriminate breast cancer from healthy controls [29]. Serum miR-10b was significantly up-regulated in metastatic (Stage M1) breast cancer compared to normal controls [74]. miR-10b expression was relatively higher in micrometastatic breast cancer cell lines BC-M1 and BC-S1 than in breast cancer cell lines MDA-MB-231 and GI-101 [74]. The regulation of mir-10b on tumor metastasis was observed in vitro and in vivo. Moriarty et al. discovered that exogenously expressed miR-10b in breast cancer cell lines, SUM159PT and SUM149PT, could repress cell migration and invasion. While down-regulated miR-10b in T47D and MDA-MB-435 cells could induce cell migration and invasion [83]. miR-10b directly targets Tiam1 to decrease the Rac activation, which influences cell metastasis. In another study, Ma and colleagues found that miR-10b had higher expression in metastatic breast cancer cell lines than non-metastatic or normal epithelial cells [84]. Knockdown of miR-10b in metastatic breast cancer cells inhibits invasion and migration, but not cell viability, or vice versa. Over-expression of miR-10b in non-metastatic cell lines induces invasion and migration. Invasion and distant metastasis in breast cancer occurred in mice when implanted with miR-10b over-expressing cells, but not in control mice. miR-10b directly targets and suppresses the expression and translation of HOXD10, which functions in the inhibition of metastasis-leading gene RHOC[85].

miR-17-92 Cluster (miR-17-3p, 17-5p, miR-18,
miR-19a, miR-19b, miR-20a, and miR-92a). In plasma, elevated miR-17-3p and miR-17-5p levels were found in colorectal cancer (CRC) [86] and gastric cancer (GC) [42] respectively, but serum miR-17-5p was reduced in non-small cell lung cancer [87]. Increased expression of miR-20a was found in the plasma of chronic lymphocytic leukemia (CLL) patients [88] and in the serum of individuals with gastric cancer [89].

miR-21. Differential expression of miR-21 was reported not only in many solid tumors, but also in hematological cancers. Over-expressed miR-21 reflects tumor malignancy and the ability of invasion and metastasis in cells by negatively regulating several known tumor suppressor genes. Validated target genes of miR-21 includes MARCKS [90], ANP32A [91], SMARCA4 [91], BMPR 2 [92], PTEN [93], ANKRD46 [94], PDCD4 [95, 96], TPM1 [97], MSH2 [98], TIMP3 [99], RASA1, TGFB1 and RASGRP1[100]. miR-21 is associated with tumor prognosis, as well as resistance to chemotherapy. In circulation, augmented expression of plasma miR-21 in ESCC was associated with vascular invasion and recurrence [39]. miR-21 was highly expressed in the serum of patients with human primary HCC [101] as well as tissue biopsy samples and cell lines compared to normal controls [93] [102]. Inhibition of miR-21 prohibited cell proliferation, invasion and metastasis in HCC cell lines [93].

Lawrie et al. demonstrated that miR-21 was elevated in de novo diffuse large B-cell lymphoma (DLBCL) samples and cell lines compared to normal B cells [103]. Serum miR-21 was expressed higher in DLBCL than in healthy subjects [104]. Interestingly, DLBCL patients with high levels of serum miR-21 demonstrated prolonged relapse-free survival time [104]. This is consistent with the observation that high miR-21 in cells is associated with better prognostic outcome in DLBCL patients [103]. In addition, miR-21 is overexpressed in the cerebrospinal fluid (CSF) of patients with primary diffuse large B-cell lymphomas (primary central nervous system lymphoma, PCNSL) [105].

Serum miR-21 was expressed significantly higher in patients with hormone-refractory prostate cancer (HRPC) than in those with localized prostate cancer, androgen-dependent prostate cancer (ADPC) and BPH [106]. Furthermore, serum miR-21 was elevated in HRPC patients with chemo-resistance. The high serum miR-21 levels found in ADPC and HRPC, but not in localized prostate cancer patients, was associated with high serum prostate-specific antigen (PSA) levels. The level of PSA is closely related to cancer development and treatment response. Hence, miR-21 was believed to serve as biomarker in prostate cancer to monitor cancer progression and treatment re- 
sponses. Correspondingly, miR-21 was significantly higher in patients with prostate cancer than normal controls and was up-regulated in cases of metastasized prostate cancer as compared to those with localized / local advanced diseases [107]. The prostate cancer cell lines, DU-145 and PC-3, which are less androgen-dependent, malignant, and metastatic cells, showed elevated miR-21 expression level [90]. Knockdown of miR-21 sensitized DU-145 and PC-3 cells to apoptosis induced by staurosporine (STS), as well as inhibited cell invasion.

Increased serum miR-21 could distinguish patients with pancreatic ductal adenocarcinoma (PDAC) from those with chronic pancreatitis $(\mathrm{CP})$ and healthy subjects [108]. In pancreatic MIA PaCa-2 cell lines, miR-21 directly targets $\mathrm{Bcl}-2$ gene and up-regulates the expression of Bcl-2 [109]. Transfection with miR-21 mimic significantly restrained caspase- 3 activity and apoptosis thus enhanced cell proliferation in MIA PaCa-2 cells. Additionally, elevated miR-21 expression accelerated the rate of cell growth under the treatment of gemcitabine, which suggests that high level of miR-21 diminished the chemo-sensitivity of MIA PaCa-2 cells. Moreover, miR-21 could distinguish non-invasive precursor of PDAC, intraductal papillary mucinous neoplasms IPMNs, [110] and the stage III lesions of pancreatic intraepithelial neoplasia (PanIN) [111] from other early stage neoplasia or normal ductal epithelium.

Plasma miR-21 was elevated in patients with NSCLC, particularly in stage T3-4, as compared to normal controls, and could be used to distinguish between tumors in stage T3-4 and in stage T1-2, but not with lymph node metastasis and distant metastasis [112]. Similarly, the level of miR-21 was significantly higher in NSCLC tissues than in adjacent normal tissues. Also, miR-21 was lower in SCLC than in NSCLC cell lines [113]. Knockdown of miR-21 impeded the growth of NSCLC A549 and H1703 cell lines as well as the invasion potential of 801D cells.

miR-21 was found to be increased not only in gastric cancer tissues and cell lines [114], but also in plasma samples of gastric cancer as compared to normal controls [42]. In gastric AGS cell line, forced expression of miR-21 promotes cell proliferation, invasion and migration, but hinders apoptosis. In addition, there is an inverse correlation between RECK and miR-21 expression in both gastric cancer tissues and cell lines. Matrix metalloproteases (MMPs), including MMP9, MMP2, and MMP14 regulated by RECK, are closely related to tumor metastasis [114].

Serum miR-21 is significantly increased in breast cancer [115], especially in stage IV cancer [116]. The level of miR-21 in matching tissue and serum was much greater in grade III breast cancer than in benign tumor or ER-/PR- breast cancer [115]. In addition, miR-21 expression was higher in breast cancer tissues than in normal controls, especially in patients with lymph node metastasis [99]. Inhibition of miR-21 resulted in restrained cell growth in ER+ MCF-7 cells $[94,95]$ and hindered invasion and metastasis, but not in ER- MDA-MB-231 cells [94, 117]. In mouse models, lung metastasis was reduced when injected with the miR-21 inhibitor-transfected MDA-MB-231 cells [117], while tumor size in xenograft mice was decreased when injected with miR-21 inhibitor-transfected MCF7 cells [94].

Hormone-dependent breast cancers could be treated by blocking the interaction between hormones and receptors on cancer cells. The resistance of trastuzumab, an anti-Her2 monoclonal antibody, in Her2 ${ }^{+}$breast cancer was strongly correlated with PTEN reduction. Gong and colleagues demonstrated that highly expressed miR-21 in trastuzumab-resistant Her2 ${ }^{+}$breast cancer cell lines BT474, SKBR3 and MDA-MB-453 resulted in decreased PTEN protein level [118]. However, the inhibition of miR-21 induced Her2 ${ }^{+}$breast cancer cells to become sensitive to trastuzumab via elevated expression of PTEN. In a similar vein, miR-21 was up-regulated and PTEN protein levels were relatively low in patients who were resistant to trastuzumab as compared to those sensitive to trastuzumab. Estradiol (E2) treated ER+ breast cancer MCF-7 cells significantly reduced the expression of endogenous miR-21 [100]. On the other hand, the all-trans-retinoic acid (ATRA) treatment, an anti-proliferative agent, provoked the expression of miR-21 in MCF-7 cells [119]. MCF-7 cells sensitized to ATRA by knockdown of miR-21 displayed significant cell growth inhibition. Another ER+ cell line, T47D, was also sensitive to ATRA and displayed reduced cell growth after ATRA treatment along with elevated miR-21 levels. The inhibition of motility in MCF-7 and T47D cells by ATRA could be lessened by ectopic down-regulation of miR-21.

miR-24. miR-24 is highly expressed in oral squamous cell carcinoma (OSCC) tissues, plasma and cell lines (OC3, OECM-1 and SAS) [120], particularly, in tongue squamous cell carcinoma (TSCC), the most common type of OSCC [121]. DND1, which regulates CDKN1B and subsequently controls the cell cycle, was verified as a target gene of miR-24 in TSCC by reporter gene assays [121].

miR-92a. In serum samples, the level of miR-92a was increased in epithelial ovarian cancer [122]. Noteworthy were the three cases with normal pre-operative CA-125 $(<35 \mathrm{U} / \mathrm{ml})$ showing highly expressed miR-92a [122], which implied that serum 
miRNAs could be used as biomarkers for early detection of ovarian cancer patients with normal CA-125.

Plasma miR-92a were up-regulated in patients in colorectal cancer (CRC) $[41,86]$ as well as advanced adenomas [41] as compared to controls. Advanced adenomas is a benign lesion with a high risk of developing into malignant CRC [123]. The early screening for advanced adenomas and precancerous lesions could diminish the occurrence of CRC $[41,124,125]$. Therefore, circulating miR-92a could serve as a biomarker on early detection of the benign lesion, advanced adenomas, before neoplastic formation of CRC.

Using miRNA microarray technology, Tanaka et al. identified 148 miRNAs in normal plasma samples, with miR-638 being the most constantly expressed miRNA [126]. They discovered that in acute myeloid leukemia (AML) plasma samples, the signal intensity of miR-92a was significantly low. The ratio of miR-92a to miR-638 in plasma was reduced in leukemia patients as compared to normal controls. The same strategy was used to examine plasma samples of patients with HCC, which also revealed a decreased miR-92a to miR-638 ratio, and increased after surgery [43]. However, the expression of circulating and tissue miR-92a was discordant in both AML/ALL and HCC. In AML and ALL leukemic cells, miR-92a was highly expressed. miR-92a was higher in AML and ALL cell lines than in both CD34+ cells and peripheral blood mononuclear cell (PBMNC) controls from healthy volunteers [127]. Cell to plasma ratio of miR-92a expression was significantly higher in fresh ALL and AML cells than in PBMNC cells. miR-92a showed significantly different expression patterns in ALL. Fresh ALL cells expressed greater miR-92a levels than both AML and PBMNC. Furthermore, ALL patients with three-fold or higher of miR-92a expression than normal PBMNC cells had decreased survival rates. Additionally, in both HCC section samples and cell lines, Shigoka et al. found that miR-92a expression was increased. Over-expressed miR-92a promoted cell proliferation in HCC cell lines.

miR-122. Serum miR-122 were significantly increased in HCC as compared to normal controls, but not as high as in hepatitis B [101]. Xu and colleagues claimed that miR-122 might be related to liver damage, and not necessarily specific to tumor development. mir-122 is known as a liver-specific miRNA and rich in adult liver [128]. In fact, many studies showed that the level of miR-122 was low in HCC cell lines and tissue samples. The anti-tumorigenic characteristics and decreased expression of miR-122 in HCC are closely associated with tumor cell growth, invasion and metastasis both in vivo and in vitro.
In HCC cell lines, such as Hep3B, PLC/PRF/5, Huh7 and SNU449, there is little to none miR-122 expression. Ectopic expression of miR-122 could drastically restrain tumor cell growth by down-regulating the expression of CCNG1 [129] and Bcl-w [129, 130], with reduced cell viability and increased apoptosis by activating caspase-3 [128]. Also, it could increase $\mathrm{G}_{1}$-phase population and inhibit tumor cell invasion, and indirectly enhance transcriptional activity of p53 [131] in HCC cells. Potentially, miR-122 could not only activate cell apoptosis via negatively regulating Bcl-w but also block cell cycle progression by down-regulating CCNG1 in HCC cells.

Overexpression of miR-122 mediated cell morphology changes and loss of actin [132], resulting in decreased cell proliferation, colony formation and migration [133] in various HCC cells, thus, suppressed tumor growth and neoangiogenesis in mice models [132, 133]. Suppression of miR-122 in Huh7 cells enhanced cell proliferation, replication potential, invasive ability and clonogenic survival. These effects were regulated by miR-122 target genes, such as the ADAM family genes $[132,133]$, which are involved in cell adhesion, invasion and metastasis.

Tissues samples with low levels of miR-122 displayed a significant correlation between time to recurrence [131] and intrahepatic metastasis in clinical diagnosis [132]. Relatively low levels of miR-122 in HCC tissue samples were associated with shorter overall survival time, larger tumor size and enhanced cell proliferation, as well as highly expressed c-Met and TGF- $\beta$ genes [134]. This suggests that the suppression of miR-122 in HCC tumors is strongly related to poor prognosis and aggressive tumor development.

miR-141. Plasma miR-141 was expressed higher in colorectal cancer stage IV than in any other early stage cases and the normal, but was not significantly different between overall patients with CRC and normal controls [135]. It also showed that up-regulated plasma miR-141 was correlated to distant metastatic colon cancer and poor survival. The combination of miR-141 and CEA improved the ability to discriminate between CRC stages. However, Cheng et al. found that there is no significant difference between the level of miR-141 in stage IV tumor and in early stages as well as adjacent normal tissues. Conversely, a study discovered that miR-141 was expressed relatively lower in SW60 CRC cell line which was derived from a metastatic site different from other cell lines [136]. It is believed that miR-141 directed cell migration and invasion by targeting the SIP1 gene. Smad interacting protein 1 (SIP1) is known to suppress the expression of E-cadherin and induce epithelial-tomesenchymal transition (EMT), which is 
essential for metastasis [137, 138]. Overexpressed miR-141 in the SW60 cell line inhibited cell migration and invasion.

miR-141 was also expressed higher in prostate tumor tissues than in normal tissues [139]. Serum miR-141 was found to be increased in prostate cancer and related to PSA level [44]. In patients diagnosed with metastatic prostate cancer, level of miR-141 was significantly higher than in patients with localized advanced disease [107]. Up-regulated miR-141 was associated with patients diagnosed with adverse risk factors (such as high Gleason score, lymph-node involvement or distant metastasis) as miR-141 was elevated in patients with high-risk tumors with a Gleason score $\geq 8$.

miR-155. miR-155 is known as a multifunctional microRNA which is involved in cancer development, inflammation, immune response and hematopoietic lineage differentiation [140]. In circulation, serum miR-155 is decreased in epithelial ovarian cancer [122] and NSCLC [87]. miR-155 had a relatively lower expression level in whole blood samples of prostate, colon, renal cancer and melanoma patients than in normal controls, except in breast cancer [82].

Plasma miR-155 increased in pancreatic ductal adenocarcinoma (PDAC)[141], suggesting elevated serum miR-155 could discriminate PDAC from normal controls [108]. Likewise, miR-155 was elevated in PDAC tissue samples and targeted the 3'-UTR of TP53INP1 gene, which is associated with pancreatic tumor development [142]. In the non-invasive precursor of PDAC, pancreatic intraepithelial neoplasia (PanIN) [111] and intraductal papillary mucinous neoplasm (IPMN) [110] lesions, miR-155 was expressed higher and further differentiated the stage of PanIN-3 and PanIN-2 from PanIN-1 and normal ductal epithelium. High levels of miR-155 in PADC patients were related to poor survival rates [143]. It seems that miR-155 is important in the progression of pancreatic adenocarcinoma and could be used in early neoplastic stage identification.

Serum miR-155 was elevated in patients with DLBCL as compared to normal subjects [104]. The expression of miR-155 and miR-21 were higher in DLBCL samples than in normal peripheral blood B cells and also higher in activated B cell-like (ABC)-type cases compared to germinal center B cell-like (GCB)-type cases [144-146]. In DLBCL and Hodgkin lymphoma (HL), high levels of the non-coding BIC gene, which serves as a primary miRNA, are associated with an over-expression of miR-155 [147]. miR-155 was expressed higher in HL than in DCBCL cell lines [148].

The level of serum miR-155 was differentially elevated in patients with post-operatively primary (M0) and metastasis (M1) as compared to healthy subjects [74]. The breast cancer cell lines MDA-MB-231, GI-101 and the micrometastatic breast cancer cell lines BC-M1 and BC-S1 served as references to confirm the expression of chosen miRNAs in serum. miR-155 level was higher in BC-M1 and BC-S1 cells as compared to MDA-MB-231 and GI-101 cells. Wang and colleagues showed that miR-155 expression was higher in breast cancer tissues and matching serums than in normal samples [115]. miR-155 in both tissue and serum were much greater in grade III than in benign breast cancers. Furthermore, over-expressed miR-155 promoted proliferation of breast cancer cell lines and tumor growth in xenograft models [149].

Studies revealed that miR-155 was related to chemo-sensitivity of breast cancer [150]. In BT-474 cells that expresses low levels of miR-155, ectopically expressed miR-155 made cells become resistant to chemotherapeutic agents such as doxorubicin, VP16, and paclitaxel. Similarly, the suppression of miR-155 in highly endogenous miR-155 expressing HS578T cells promoted the apoptosis ability of chemotherapeutic agents. FOXO3a was a direct target of miR-155 in breast cancer cell lines and the inverse correlation between FOXO3a protein and miR-155 were demonstrated in both breast tumor tissues and cell lines [150]. Due to the downstream regulation of pro-apoptotic and growth inhibiting genes by FOXO3a, increased miR-155 induced cell survival and diminished miR-155 stimulated apoptosis.

miR-195. The level of whole blood miRNA-195 was greatly elevated in patients diagnosed with breast cancer from stage I to IV, than in age-matched disease-free individuals [29]. It is suggested that circulating miRNAs could be detected during early stages of breast cancer. In addition, the expression of miR-195 in age- and stage-matched tumor tissues were compared with whole blood samples [29]. In both tumor tissues and circulation, the levels of miR-195 were increased at progressive stages of breast cancer, which means that miRNA-195 was expressed higher in stage IV than in stage I or II. It reflected the similar trend of miR-195 expression in tissue and circulation as well as the positive correlation between tissue and circulating miR-195. Later, Heneghan and colleagues proved that circulating miR-195 could be used as a breast cancer specific biomarker [82]. Compared to the normal, significantly high level of miR-195 was observed only in preoperative whole blood samples of breast cancer, but not in other cancers, such as colon, prostate, renal and melanoma.

However, Li et al. showed that miR-195 expression was decreased in breast cancer tissues and cell 
lines, and they further validated that Raf-1 and CNND1 are direct target genes for miR-195 [151]. Another study also indicated that miR-195 was lower in ductal carcinoma in situ (DCIS) than in normal epithelium or reduction mammoplasty [152]. Moreover, lower expression levels of miR-195 implied the possible tumor suppressor characteristic of miR-195 in colorectal cancer [153] as well as in hepatocellular carcinoma [154]. Bcl2, which is known as an anti-apoptotic gene, and CCND1, CDK6 and E2F3, cell cycle-related genes, were direct targets of miR-195 in colorectal cancer [153] and hepatocellular carcinoma [154] respectively. In functional analysis, transfection of miR-195 inhibited cell growth and invasive ability, by blocking the G1 cell cycle of tumor cells in breast cancer and hepatocellular carcinoma [154, 155], and inducing cell apoptosis in colorectal cancer [153]. These studies demonstrated the role of miR-195 in cell cycle regulation and tumor development.

miR-221. Plasma miR-221 was higher in CRC patients than in normal controls and the greater expression of miR-221 was associated with a shorter overall survival rate [156]. Other studies that explored miR-221 in the plasma of prostate cancer cases found increased levels compared to controls [107, 157]. The level of miR-221 was higher in patients with metastasized prostate cancer than in those with local advanced disease and healthy controls [107].

Similarly, miR-221 was more elevated in plasma of Androgen-dependent (ADPC) and Androgen-independent (AIPC) prostate carcinoma than in normal cases [157]. The level of miR-221 was higher in plasma of ADPC than that of AIPC. miR-221 was expressed significantly higher in prostate cancer cell line PC3 than in normal human prostate epithelial cells RWPE-1. miR-221 down-regulated the ARHI gene by targeting the 3'-UTR region [158]. Likewise, miR-221 was found at a comparatively higher expression level in the androgen-independent, strongly aggressive PC3 cell line than in the androgen-responsive 22Rv1 cells as well as in the androgen dependent, slowly growing LNCaP cells [159]. The p27 gene, which prohibits the G1/S cell-cycle transition, was validated as a direct target of miR-221 by reporter gene assay. After transfection, forced miR-221 could diminish the expression of $\mathrm{p} 27$, therefore to promote cell proliferation, and to increase $S$ phase population and the number of colonies in the LNCaP cells. Transfected anti-miR-221 in PC3 cells showed comparable effects on colony formation: a declined colony growing in soft agar. This indicates that miR-221 has the ability to make prostate cancer cells more aggressive, which could grow in an anchorage-independent way, and promote tumor cell growth by negatively regulating the p27 gene.

A lower expression level of serum miR-221 was found in NSCLC than in healthy subjects, while miR-221 levels were higher in both NSCLC cell lines as well as tissue samples when compared with controls [160]. Overexpression of miR-221 down-regulated tumor suppressor genes PTEN and TIMP3, and enhanced cell migration and invasive ability in cell lines and stimulated the resistance of TRAIL-inducing apoptosis in NSCLC cells.

miR-375. The expression of serum miR-375 was greater in prostate cancer than in normal controls, and greater in metastasized cancer than in primary prostate cancer [139]. Serum miR-375 increased in cases with lymph-node positive prostate cancer and presented a close relationship between greater levels of serum miR-375 and patients diagnosed with adverse risk factors (high Gleason score, lymph-node involvement or distant metastasis). A microarray platform and validation by qRT-PCR revealed that miR-375 was up-regulated in prostate tumor tissues [161].

\section{Method challenges in cell-free circulating miRNA study}

Serum specimens contain high volumes of protein, and therefore extraction requires a modified protocol that adds more denaturing solution such as Qiazol or Trizol [162]. Additionally, considering the small amount of RNAs from serum or plasma samples, a routine spike-in synthetic non-human C.elegan miRNA (e.g. Cel-miR-39) was used after the initial serum denaturation step to serve as the internal quality control [163]. Another technical challenge is that the quality metrics derived from traditional spectrophotometry might be uninformative and inaccurate due to the low concentration of RNA from serum or plasma. The spike-in synthetic miRNAs are therefore important for adjusting the differences and filtering the outliers in the samples.

Considering that profiling of circulating miRNAs are frequently confounded by cellular miRNAs, we believe that cell-free circulating miRNAs from exosomes will be a better starting material for profiling studies. Unfortunately, cross-contamination between cells and exosomes seem to be unavoidable. The alternative might be to enrich exosome fractions and eliminate cell fractions. In order to enhance the specificity of potential circulating miRNAs, we recommend the blood plasma and serum preparation protocol modified by Duttagupat et al.[164]. For better targeting the tumor-derived exosomes, tumor-antibody coupled magnetic beads could be used to enrich the tumor relevant miRNAs [165]. Once po- 
tential exosomal miRNA biomarkers are identified, they could be validated by using whole blood or unfractioned serum or plasma.

Moreover, in the assessment of whether RNA isolation is cell-free, three main parameters should be investigated by qPCR: i). The existence of high and constantly expressed serum/plasma miRNAs, such as miR-16, miR-223 or let-7a [166]. These miRNAs have been reported to keep consistent expression levels among plasma / serum and are correlated with the number of blood cells. Great variance of their expression levels might indicate possible contamination from blood cellular miRNAs. ii). The absence of typical blood cellular miRNAs, including miR-20a, miR-106a, miR-185 and miR-144 [167]. Expression of these miRNAs seems to be exclusive in white and red blood cells. Positive signals for these miRNAs might indicate that cells have lysed during the procedure. iii). The absence of qPCR enzymatic reaction inhibitor. Protein-rich plasma / serum could have some qPCR inhibitors, which will distort the results and further skew the metrics to establish a predictor system. The presence of inhibitors means the raw $\mathrm{Ct}$ value will not increase alongside an increasing RNA input. To rule out the possibility, a standard curve of the consistently expressed miRNAs, such as spike-in miRNAs, on a serial dilution of samples may be used.

There is no consensus right now in using endogenous reference miRNAs to normalize miRNA qPCR results. miRNA expression levels can vary significantly depending on the tissue types, for instance, reference miRNAs might be consistently expressed in breast cells but aberrantly expressed in prostate cells. Other alternative methods, including small RNAs (most commonly used 5S, U6), total RNA, or $18 \mathrm{~S}$ rRNA, may not be applicable in plasma or serum miRNA analysis. For example, 5S and U6 are not present in plasma and serum.

\section{Conclusions}

The emergence of miRNAs as the mediator of gene expression in carcinogenesis renders themselves as promising potential diagnostic markers for malignancy. They are also found to be surprisingly stable in RNase-rich serum and plasma environment, which strengthens its feasibility as a routine clinical screening method. A number of recent studies documented altered miRNA expression in circulation by comparing tumor patients with healthy individuals, indicating their putative role as cancer biomarkers. Also, new models have been proposed that suggest circulating miRNAs might be released from the tumor tissue to adjacent or distant cells in an autocrine or paracrine manner, and this paradigm was strength- ened by the detection of tumor driven miRNAs in circulating small vesicles, including exosomes and HDL, etc. However, several issues must be addressed before they can be validated as biomarkers for cancer.

It is challenging to avoid the interference of blood cell miRNAs in serum/plasma miRNA profiling. Our focus is to distinguish the tumor-derived miRNAs from those of the blood cells. Tumor-associated antigen presenting exosomes might provide an alternative way to address this paradox. However, limited research has been done to distinguish the efficiency of the antibody between tumor-derived exosomes and other tissue derived exosomes. In addition, other miRNA-carrying microvesicles, such as HDL, or even RNA-binding proteins like Ago 2, broadened our knowledge of circulating miRNAs and their transportation and delivery. More complex questions arise, such as whether specific miRNAs select certain carriers, or vice versa. Further elucidation of this mechanism might allow us to tailor particular starting materials depending on diseases.

Researchers might also argue whether or not circulating miRNA profiling can reflect the carcinogenesis process. In other words, are the altered miRNAs identified in circulation truly correlated to focal tumor progression with real biological function? Systematic validation on cells lines, human biopsy specimens and Formalin-Fixed, Paraffin-Embedded (FFPE) tissue might address these questions. However, if the aforementioned selective miRNA-carrier model exists, solely whole blood or whole serum/plasma miRNA profiling studies might not be appropriate. Nevertheless, the methodology of profiling circulating miRNAs is still challenging. For example, the lack of a reliable endogenous miRNA control for normalization makes it hard to evaluate the level of miRNAs in circulation between studies [168]. Since gene expression is known to vary within a population, in order to obtain miRNA signatures related to diseases, it is important to determine the range of normal variability across demographic populations [164].

It is known that the signatures of serum/plasma miRNAs may reflect correlations to physiological or disease conditions. Further research on how cells secrete miRNAs to extracellular environment is crucial for targeting proper objects, which truly reflect cancer cell carcinogenesis. It is also essential to explore direct or indirect biological functions that circulating miRNAs may have on distant cells [61]. We expect that study of cell-free circulating miRNAs would result in novel molecular biomarkers for early cancer diagnosis and management. 
Table I. Expression of miRNAs in circulation of various cancers, along with their target genes and pathways involved.

\begin{tabular}{|c|c|c|c|c|}
\hline Types of Cancer & $\begin{array}{l}\text { Altered miRNAs and Regulation } \\
\text { in Circulation }\end{array}$ & $\begin{array}{l}\text { Verified Target Genes in } \\
\text { Cells and/or Tissues }\end{array}$ & Program Predicted Pathway* & $p$ value \\
\hline $\begin{array}{l}\text { Acute Leukemia } \\
\text { (AML \& ALL) }\end{array}$ & $\downarrow$ miR-92a (plasma) [126] & & $\begin{array}{l}\text { Molecular Mechanisms of Cancer } \\
\text { Integrin Signaling } \\
\text { RAR activation }\end{array}$ & $\begin{array}{l}1.77 \mathrm{E}-22 \\
9.78 \mathrm{E}-11 \\
9.54 \mathrm{E}-09\end{array}$ \\
\hline \multirow[t]{11}{*}{ Brest Cancer } & $\downarrow$ let-7c (plasma) [28] & & $\begin{array}{l}\text { Molecular Mechanisms of Cancer } \\
\text { Wnt/ } \beta \text {-catenin Signaling }\end{array}$ & $\begin{array}{l}1 \mathrm{E}-35 \\
8.55 \mathrm{E}-18\end{array}$ \\
\hline & $\uparrow \mathrm{miR}-589$ (plasma) [28] & & $\begin{array}{l}\text { Molecular Mechanisms of Cancer } \\
\text { NF-kB Signaling }\end{array}$ & $\begin{array}{l}1.07 \mathrm{E}-04 \\
2.62 \mathrm{E}-04\end{array}$ \\
\hline & $\begin{array}{l}\uparrow \mathrm{miR}-425 \text { (plasma) }[28] \\
\uparrow \mathrm{miR}-21 \text { (serum) }[115,116]\end{array}$ & $\begin{array}{l}\text { PTEN [118],PDCD4 [100, 117, } \\
\text { 169-171], RTN4, NCAPG, } \\
\text { DERL1, PLOD3, BASP1 [171], } \\
\text { Maspin [117], RASA1, } \\
\text { TGFB1,RASGRP1 [100], } \\
\text { ANKRD46 [94], MSH2 [98], } \\
\text { ICAM-1,PLAT,IL1B[119], } \\
\text { TIMP3 [99], TPM1[97] }\end{array}$ & $\begin{array}{l}\text { Molecular Mechanisms of Cancer } \\
\text { TGF- } \beta \text { Signaling } \\
\text { Wnt } / \beta \text {-catenin Signaling } \\
\text { PTEN Signaling }\end{array}$ & $\begin{array}{l}1.11 \mathrm{E}-19 \\
6.68 \mathrm{E}-09 \\
8.35 \mathrm{E}-07 \\
9.96 \mathrm{E}-07\end{array}$ \\
\hline & $\uparrow \mathrm{miR}-34 \mathrm{a}$ (serum) [74] & Axl [172] & $\begin{array}{l}\text { Molecular Mechanism of Cancer } \\
\text { ERK/MARK Signaling } \\
\text { Wnt/ } \beta \text {-catenin Signaling } \\
\text { PI3k/AKT Signaling }\end{array}$ & $\begin{array}{l}1.13 \mathrm{E}-41 \\
1.38 \mathrm{E}-35 \\
1.04 \mathrm{E}-20 \\
6.42 \mathrm{E}-20\end{array}$ \\
\hline & $\uparrow \mathrm{miR}-106 \mathrm{a}$ (serum) [115] & & $\begin{array}{l}\text { ERK/MARK Signaling } \\
\text { PTEN Signaling }\end{array}$ & $\begin{array}{l}2.26 \mathrm{E}-19 \\
2.44 \mathrm{E}-18\end{array}$ \\
\hline & $\downarrow \mathrm{miR}-126$ (serum) [115] & IRS-1 [173] & PDGF signaling & 6.67E-05 \\
\hline & $\uparrow \mathrm{miR}-155$ (serum) [74, 115] & SOCS1 [149], FOXO3a [150] & & \\
\hline & $\downarrow$ miR-199a (serum) [115] & & & \\
\hline & $\downarrow$ miR-335 (serum) [115] & & $\begin{array}{l}\text { Molecular Mechanisms of Cancer } \\
\text { Role of BRCA1in DNA Damage Re- } \\
\text { sponse }\end{array}$ & $\begin{array}{l}4.71 \mathrm{E}-04 \\
1.7 \mathrm{E}-03\end{array}$ \\
\hline & $\uparrow \mathrm{miR}-195$ (whole blood) $[29,82]$ & CCND1 [27] & $\begin{array}{l}\text { Molecular Mechanisms of Cancer } \\
\text { PTEN Signaling } \\
\text { PI3K/AKT Signaling } \\
\text { Wnt/ } \beta \text {-catenin Signaling }\end{array}$ & $\begin{array}{l}6.15 \mathrm{E}-33 \\
2.87 \mathrm{E}-23 \\
1.52 \mathrm{E}-19 \\
3.07 \mathrm{E}-19\end{array}$ \\
\hline & $\uparrow$ let-7a (whole blood) $[29,82]$ & & & \\
\hline $\begin{array}{l}\text { Chronic Lympho- } \\
\text { cytic Leukemia } \\
\text { (CLL) }\end{array}$ & $\uparrow \mathrm{miR}-195$ (plasma) [88] & & & \\
\hline \multirow{8}{*}{$\begin{array}{l}\text { Colorectal Cancer } \\
(\mathrm{CRC})\end{array}$} & $\uparrow \mathrm{miR}-17-3 p$ (plasma) [174] & & & \\
\hline & $\uparrow \mathrm{miR}-29 \mathrm{a}$ (plasma) [41] & & $\begin{array}{l}\text { Molecular Mechanisms of Cancer } \\
\text { IL-8 Signaling } \\
\text { VEGF Signaling }\end{array}$ & $\begin{array}{l}1.8 \mathrm{E}-21 \\
2.84 \mathrm{E}-14 \\
4.64 \mathrm{E}-12\end{array}$ \\
\hline & $\uparrow m i R-92 a$ (plasma) [174] [41] & & $\begin{array}{l}\text { Integrin Signaling } \\
\text { RAR Activation }\end{array}$ & $\begin{array}{l}9.78 \mathrm{E}-11 \\
9.54 \mathrm{E}-09\end{array}$ \\
\hline & $\uparrow m i R-141$ (plasma) [135] & SIP1 [136] & $\begin{array}{l}\text { GNRH Signaling } \\
\text { Wnt/ } \beta \text {-catenin Signaling }\end{array}$ & $\begin{array}{l}1.29 \mathrm{E}-15 \\
1.87 \mathrm{E}-12\end{array}$ \\
\hline & $\uparrow \mathrm{miR}-221$ (plasma) [156] & & $\begin{array}{l}\text { ERK/MAPK Signaling } \\
\text { p53 Signaling } \\
\text { PTEN Signaling }\end{array}$ & $\begin{array}{l}9.49 \mathrm{E}-10 \\
4.04 \mathrm{E}-8 \\
1.07 \mathrm{E}-7\end{array}$ \\
\hline & ^let-7a (whole blood) [82] & & & \\
\hline & $\downarrow \mathrm{miR}-10 \mathrm{~b}$ (whole blood) [82] & & $\begin{array}{l}\text { G1/S checkpoint regulation } \\
\text { Integrin Signaling }\end{array}$ & $\begin{array}{l}8.75 \mathrm{E}-07 \\
6.05 \mathrm{E}-06\end{array}$ \\
\hline & $\downarrow$ miR-155 (whole blood) [82] & & & \\
\hline Diffuse Large B-Cell & $\uparrow \mathrm{miR}-21$ (serum) [104] & & & \\
\hline Lymphoma & $\uparrow \mathrm{miR}-155$ (serum) [104] & $\begin{array}{l}\text { SMAD5 [175], SHIP1[146], } \\
\text { AGTR1,FGF7,ZNF537,ZIC3 } \\
\text { AND IKBKE [176] }\end{array}$ & & \\
\hline
\end{tabular}




\begin{tabular}{|c|c|c|c|c|}
\hline \multirow{9}{*}{$\begin{array}{l}\text { Epithelial Ovarian } \\
\text { Cancer }\end{array}$} & $\uparrow \mathrm{miR}-210$ (serum) [104] & & & \\
\hline & $\uparrow \mathrm{miR}-21$ (serum) [122] & & & \\
\hline & $\uparrow \mathrm{miR}-29 \mathrm{a}$ (serum) [122] & & & \\
\hline & $\uparrow \mathrm{miR}-92 \mathrm{a}$ (serum) [122] & & & \\
\hline & $\uparrow \mathrm{miR}-93$ (serum) [122] & & & \\
\hline & $\uparrow \mathrm{miR}-99 \mathrm{~b}$ (serum) [122] & & PTEN Signaling & $1.95 \mathrm{E}-05$ \\
\hline & †miR-126 (serum) [122] & & & \\
\hline & $\downarrow \mathrm{miR}-127$ (serum) [122] & & & \\
\hline & $\downarrow$ miR-155 (serum )[122] & & & \\
\hline \multirow{13}{*}{$\begin{array}{l}\text { Esophageal Squa- } \\
\text { mous Cell Carcino- } \\
\text { ma (ESCC) }\end{array}$} & $\uparrow \mathrm{miR}-21$ (plasma) [39] & & & \\
\hline & $\downarrow$ miR-375 (plasma) [39] & & Growth Hormone Signaling & $1.15 \mathrm{E}-06$ \\
\hline & & & Prolactin Signaling & $1.53 \mathrm{E}-06$ \\
\hline & & & VDR/RXR Activation & 2E-06 \\
\hline & 个miR-10a (serum) [177] & & & \\
\hline & $\uparrow \mathrm{miR}-22$ (serum) [177] & & p53 Signaling & 3.59E-12 \\
\hline & †miR-100 (serum) [177] & & & \\
\hline & $\uparrow \mathrm{miR}-127-3 p$ (serum) [177] & & & \\
\hline & 个miR-133a (serum) [177] & & Wnt/ $\beta$-catenin signaling & 2.81E-13 \\
\hline & & & ERK/MAPK Signaling & 2.29E-11 \\
\hline & & & PTEN Signaling & 2.64E-09 \\
\hline & $\uparrow \mathrm{miR}-148 \mathrm{a}$ (serum) [177] & & ERK/MAPK Signaling & $4.11 \mathrm{E}-15$ \\
\hline & $\uparrow \mathrm{miR}-223$ (serum) [177] & & IGF-1 Signaling & $2.53 \mathrm{E}-13$ \\
\hline \multirow[t]{12}{*}{ Gastric Cancer (GC) } & $\uparrow m i R-17-5 p$ (plasma) [42] & & & \\
\hline & $\uparrow \mathrm{miR}-21$ (plasma) [42] & RECK [114] & & \\
\hline & 个miR-106a (plasma) [42] & & & \\
\hline & 个miR-106b (plasma) [42] & & & \\
\hline & $\downarrow$ let-7a (plasma) [42] & RAB40C [178] & & \\
\hline & 个miR-1 (serum) [179] & & ERK/MAPK Signaling & 2.64E-17 \\
\hline & & & PTEN Signaling & $1.54 \mathrm{E}-16$ \\
\hline & $\uparrow \mathrm{miR}-34 \mathrm{a}$ (serum) [179] & & & \\
\hline & $\uparrow \mathrm{miR}-20$ (serum) [179] & & & \\
\hline & $\uparrow \mathrm{miR}-27 \mathrm{a}$ (serum) [179] & Prohibitin [180] & PTEN Signaling & $4.26 \mathrm{E}-20$ \\
\hline & & & PPARa/RXRa activation & 1.09E-19 \\
\hline & & & PAK Signaling & 2.9E-15 \\
\hline \multirow{8}{*}{$\begin{array}{l}\text { Hepatocellular Car- } \\
\text { cinoma (HCC) }\end{array}$} & $\downarrow$ miR-92a (plasma) [43] & & & \\
\hline & $\uparrow \mathrm{miR}-21$ (serum) [101] & PTEN [93], RHOB [102] & & \\
\hline & $\uparrow \mathrm{miR}-122$ (serum) [101] & Bcl-w $[128]$ & PTEN Signaling & 3.19E-04 \\
\hline & $\uparrow \mathrm{miR}-223$ (serum) [101] & $\begin{array}{l}\text { STMN1 [181], SLC7A1, AKT3, } \\
\text { ADAM17 [132], CUTL1 } \\
\text { [182],CCNG1[130], } \\
\text { ADAM10,SRF,IGF1R[133] }\end{array}$ & & \\
\hline & $\uparrow \mathrm{miR}-500$ (serum) [183] & & & \\
\hline & $\uparrow \mathrm{miR}-885-5 p$ (serum) [184] & & Protein Kinase A signaling & $1.04 \mathrm{E}-05$ \\
\hline & & & Thrombin Signaling & 1.05E-04 \\
\hline & & & Phospholipase C Signaling & $1.84 \mathrm{E}-04$ \\
\hline \multirow[t]{2}{*}{ Melanoma } & $\downarrow$ miR-10b (whole blood) [82] & & & \\
\hline & $\downarrow$ miR-155 (whole blood) [82] & & & \\
\hline \multirow{6}{*}{$\begin{array}{l}\text { Non-small Cell } \\
\text { Lung Cancer } \\
\text { (NSCLC) }\end{array}$} & $\downarrow \mathrm{miR}-20 \mathrm{~b}$ (plasma) [185] & & & \\
\hline & $\uparrow \mathrm{miR}-21$ (plasma) [112] & PTEN [186] & & \\
\hline & $\downarrow$ miR-30e-3p (plasma) [185] & & & \\
\hline & $\downarrow$ let-7f (plasma) [185] & & & \\
\hline & $\downarrow \mathrm{miR}-1$ (serum) [187] & MET, Pim-1[77] & & \\
\hline & $\downarrow \mathrm{miR}-17-5 \mathrm{p}$ (serum) [87] & & & \\
\hline
\end{tabular}


$\uparrow \mathrm{miR}-25$ (serum) [31]
$\downarrow \mathrm{miR}-27 \mathrm{a}$ (serum) [87]
$\uparrow \mathrm{miR}-29 \mathrm{c}$ (serum) [87]
$\uparrow \mathrm{miR}-30 \mathrm{~d}$ (serum) [87]

$\downarrow$ miR-106a (serum) [87]

$\downarrow$ miR-146 (serum) [87]

$\downarrow$ miR-155 (serum) [87]

$\downarrow$ miR-221 (serum) [87]

$\uparrow$ miR-223 (serum) [31]

$\uparrow \mathrm{miR}-486$ (serum) [187]

$\downarrow$ miR-499 (serum) [187]

$\downarrow$ let-7a (serum, whole blood) [87] [188]

Oral Squamous Cell $\uparrow$ miR-24 (plasma) [120

Carcinoma (OSCC)

Pancreatic Cancer

$\begin{aligned} & {[108] } \\ & \uparrow \mathrm{miR}-155 \text { (plasma) }[141] \\ & \uparrow \mathrm{miR}-196 \mathrm{a} \text { (plasma) (seru } \\ & \uparrow \mathrm{miR}-210 \text { (plasma) }[190] \\ & \uparrow \mathrm{miR}-155 \text { (serum) [141] } \\ & \uparrow \mathrm{miR}-200 \mathrm{a} \text { (serum) }[191] \\ & \uparrow \mathrm{miR}-200 \mathrm{~b} \text { (serum) [191] }\end{aligned}$

Prostate Cancer $\quad \uparrow \mathrm{miR}-21$ (plasma) [107]

$\uparrow \mathrm{miR}-141$ (plasma) [107] (serum)

[192] [44]

$\uparrow$ miR-221 (plasma) [107] [157]

$\uparrow$ miR-375 (serum) [192]

$\uparrow$ let-7a (whole blood) [82]

$\downarrow$ miR-155 (whole blood) [82]

Rhabdomyosarcoma $\uparrow$ miR-206 [194]

(RMS)

Tongue Squamous $\quad \uparrow m i R-184$ [195]

Cell Carcinoma

(TSCC)
Wnt/ $\beta$-catenin Signaling

PTEN Signaling

Integrin Signaling

PI3K/ AKT Signaling

PPAR Signaling

RAR Activation

9.15E-20

6.19E-18

3.98E-17

$5.55 \mathrm{E}-16$

7.15E-06

7.98E-05

PTEN, TIMP3 [160]

NIRF [189]

DND1 [120]

FIH [99]

Bcl-2 [109]

TP53INP1 [142]

EFNA3 [143]

IGF-1 Signaling

1.12E-05

PI3k/AKT Signaling

2.2E-05

Wnt/ $\beta$-catenin Signaling

$1.65 \mathrm{E}-15$

PTEN Signaling

9E-14

Thrombin Signaling

ERK/MAPK Signaling

3.36E-09

7.9E-08

G1/S checkpoint regulation

5.69E-07

ERK/MAPK Signaling

Wnt $/ \beta$-catenin Signaling

$1.38 \mathrm{E}-35$

$1.04 \mathrm{E}-20$

PI3K/AKT Signaling
ANP32A, SMARCA4[91]

BMPR2[92], MARCKS[90]

p27kip1 [159], ARHI [158]

Sec23A [193]

\section{Acknowledgements}

This work was supported by the Wendy Will Case award and the NCI/NIH award (R21CA159103) to S. W. Fu. We thank Ms. Danielle Soberman for her edits and comments.

\section{Competing Interests}

The authors have declared that no competing interest exists.

\section{References}

1. Griffiths-Jones S, Grocock RJ, van Dongen S, Bateman A, Enright AJ: miRBase: microRNA sequences, targets and gene nomenclature. Nucleic Acids Res 2006, 34(Database issue):D140-144.

2. Griffiths-Jones S, Saini HK, van Dongen S, Enright AJ: miRBase: tools for microRNA genomics. Nucleic Acids Res 2008, 36(Database issue):D154-158.

3. Bentwich I, Avniel A, Karov Y, Aharonov R, Gilad S, Barad O, Barzilai A, Einat P, Einav U, Meiri E et al: Identification of hundreds of conserved and nonconserved human microRNAs. Nat Genet 2005, 37(7):766-770.

4. Berezikov E, van Tetering G, Verheul M, van de Belt J, van Laake L, Vos J, Verloop R, van de Wetering M, Guryev V, Takada S et al: 
Many novel mammalian microRNA candidates identified by extensive cloning and RAKE analysis. Genome Res 2006, 16(10):1289-1298.

5. Lewis BP, Burge CB, Bartel DP: Conserved seed pairing, often flanked by adenosines, indicates that thousands of human genes are microRNA targets. Cell 2005, 120(1):15-20.

6. Krol J, Loedige I, Filipowicz W: The widespread regulation of microRNA biogenesis, function and decay. Nat Rev Genet 2010, 11(9):597-610.

7. Kent OA, Mendell JT: A small piece in the cancer puzzle: microRNAs as tumor suppressors and oncogenes. Oncogene 2006, 25(46):6188-6196.

8. Kim VN: MicroRNA biogenesis: coordinated cropping and dicing. Nat Rev Mol Cell Biol 2005, 6(5):376-385.

9. Sioud M, Cekaite L: Profiling of miRNA expression and prediction of target genes. Methods Mol Biol 2010, 629:257-271.

10. Ambros V: The functions of animal microRNAs. Nature 2004, 431(7006):350-355.

11. Huang JC, Babak T, Corson TW, Chua G, Khan S, Gallie BL, Hughes TR, Blencowe BJ, Frey BJ, Morris QD: Using expression profiling data to identify human microRNA targets. Nat Methods 2007, 4(12):1045-1049.

12. Huang V, Place RF, Portnoy V, Wang J, Qi Z, Jia Z, Yu A, Shuman M, Yu J, Li LC: Upregulation of Cyclin B1 by miRNA and its implications in cancer. Nucleic Acids Res 2011, 40(4):1695-1707.

13. Calin GA, Sevignani C, Dumitru CD, Hyslop T, Noch E, Yendamuri S, Shimizu M, Rattan S, Bullrich F, Negrini M et al: Human microRNA genes are frequently located at fragile sites and genomic regions involved in cancers. Proc Natl Acad Sci U S A 2004, 101(9):2999-3004.

14. Zhao JJ, Yang J, Lin J, Yao N, Zhu Y, Zheng J, Xu J, Cheng JQ, Lin JY, Ma X: Identification of miRNAs associated with tumorigenesis of retinoblastoma by miRNA microarray analysis. Childs Nerv Syst 2009, 25(1):13-20.

15. Klase Z, Winograd R, Davis J, Carpio L, Hildreth R, Heydarian M, Fu SW, McCaffrey T, Meiri E, Ayash-Rashkovsky M et al: HIV-1 TAR miRNA protects against apoptosis by altering cellular gene expression. Retrovirology 2009, 6:18.

16. Lee RC, Feinbaum RL, Ambros V: The C. elegans heterochronic gene lin-4 encodes small RNAs with antisense complementarity to lin-14. Cell 1993, 75(5):843-854.

17. Brennecke J, Hipfner DR, Stark A, Russell RB, Cohen SM: bantam encodes a developmentally regulated microRNA that controls cell proliferation and regulates the proapoptotic gene hid in Drosophila. Cell 2003, 113(1):25-36.

18. Esquela-Kerscher A, Slack FJ: Oncomirs - microRNAs with a role in cancer. Nat Rev Cancer 2006, 6(4):259-269.

19. Sevignani C, Calin GA, Siracusa LD, Croce CM: Mammalian microRNAs: a small world for fine-tuning gene expression. Mamm Genome 2006, 17(3):189-202.

20. Szafranska AE, Davison TS, John J, Cannon T, Sipos B, Maghnouj A, Labourier E, Hahn SA: MicroRNA expression alterations are linked to tumorigenesis and non-neoplastic processes in pancreatic ductal adenocarcinoma. Oncogene 2007, 26(30):4442-4452.

21. Bernstein E, Kim SY, Carmell MA, Murchison EP, Alcorn H, Li MZ, Mills AA, Elledge SJ, Anderson KV, Hannon GJ: Dicer is essential for mouse development. Nat Genet 2003, 35(3):215-217.

22. Chen $\mathrm{CZ}, \mathrm{Li}$ L, Lodish HF, Bartel DP: MicroRNAs modulate hematopoietic lineage differentiation. Science 2004, 303(5654):83-86.

23. Blenkiron C, Goldstein LD, Thorne NP, Spiteri I, Chin SF, Dunning MJ, Barbosa-Morais NL, Teschendorff AE, Green AR, Ellis IO et al: MicroRNA expression profiling of human breast cancer identifies new markers of tumor subtype. Genome Biol 2007, 8(10):R214.

24. Verghese ET, Hanby AM, Speirs V, Hughes TA: Small is beautiful: microRNAs and breast cancer-where are we now? I Pathol 2008, 215(3):214-221

25. Sassen S, Miska EA, Caldas C: MicroRNA: implications for cancer. Virchows Arch 2008, 452(1):1-10.

26. Calin GA, Liu CG, Sevignani C, Ferracin M, Felli N, Dumitru CD, Shimizu M, Cimmino A, Zupo S, Dono M et al: MicroRNA profiling reveals distinct signatures in $B$ cell chronic lymphocytic leukemias. Proc Natl Acad Sci U S A 2004, 101(32):11755-11760.
27. Gaur A, Jewell DA, Liang Y, Ridzon D, Moore JH, Chen C, Ambros VR, Israel MA: Characterization of microRNA expression levels and their biological correlates in human cancer cell lines. Cancer Res 2007, 67(6):2456-2468.

28. Zhao H, Shen J, Medico L, Wang D, Ambrosone CB, Liu S: A pilot study of circulating miRNAs as potential biomarkers of early stage breast cancer. PLoS One 2010, 5(10):e13735.

29. Heneghan HM, Miller N, Lowery AJ, Sweeney KJ, Newell J, Kerin MJ: Circulating microRNAs as novel minimally invasive biomarkers for breast cancer. Ann Surg 2010, 251(3):499-505.

30. Chin LJ, Slack FJ: A truth serum for cancer--microRNAs have major potential as cancer biomarkers. Cell Res 2008, 18(10):983-984.

31. Chen X, Ba Y, Ma L, Cai X, Yin Y, Wang K, Guo J, Zhang Y, Chen J, Guo $X$ et al: Characterization of microRNAs in serum: a novel class of biomarkers for diagnosis of cancer and other diseases. Cell Res 2008, 18(10):997-1006.

32. Vickers KC, Remaley AT: Lipid-based carriers of microRNAs and intercellular communication. Curr Opin Lipidol 2012, 23(2):91-97.

33. Arroyo JD, Chevillet JR, Kroh EM, Ruf IK, Pritchard CC, Gibson DF, Mitchell PS, Bennett CF, Pogosova-Agadjanyan EL, Stirewalt DL et al: Argonaute2 complexes carry a population of circulating microRNAs independent of vesicles in human plasma. Proc Natl Acad Sci U S A 2011, 108(12):5003-5008.

34. Zhang Y, Liu D, Chen X, Li J, Li L, Bian Z, Sun F, Lu J, Yin Y, Cai X et al: Secreted monocytic miR-150 enhances targeted endothelial cell migration. Mol Cell 2011, 39(1):133-144.

35. Muller G, Schneider M, Biemer-Daub G, Wied S: Microvesicles released from rat adipocytes and harboring glycosylphosphatidylinositol-anchored proteins transfer RNA stimulating lipid synthesis. Cell Signal 2011, 23(7):1207-1223.

36. Turchinovich A, Weiz L, Langheinz A, Burwinkel B: Characterization of extracellular circulating microRNA. Nucleic Acids Res 2011, 39(16):7223-7233.

37. Gallo A, Tandon M, Alevizos I, Illei GG: The Majority of MicroRNAs Detectable in Serum and Saliva Is Concentrated in Exosomes. PLoS One 2012, 7(3):e30679.

38. LaConti JJ, Shivapurkar N, Preet A, Deslattes Mays A, Peran I, Kim SE, Marshall JL, Riegel AT, Wellstein A: Tissue and serum microRNAs in the Kras(G12D) transgenic animal model and in patients with pancreatic cancer. PLoS One 2011, 6(6):e20687.

39. Komatsu S, Ichikawa D, Takeshita H, Tsujiura M, Morimura R, Nagata H, Kosuga T, Iitaka D, Konishi H, Shiozaki A et al: Circulating microRNAs in plasma of patients with oesophageal squamous cell carcinoma. Br J Cancer 2011, 105(1):104-111.

40. Liu CJ, Kao SY, Tu HF, Tsai MM, Chang KW, Lin SC: Increase of microRNA miR-31 level in plasma could be a potential marker of oral cancer. Oral Dis 2010, 16(4):360-364.

41. Huang Z, Huang D, Ni S, Peng Z, Sheng W, Du X: Plasma microRNAs are promising novel biomarkers for early detection of colorectal cancer. Int J Cancer 2010, 127(1):118-126.

42. Tsujiura M, Ichikawa D, Komatsu S, Shiozaki A, Takeshita $\mathrm{H}$, Kosuga T, Konishi H, Morimura R, Deguchi K, Fujiwara H et al: Circulating microRNAs in plasma of patients with gastric cancers. Br J Cancer 2010, 102(7):1174-1179.

43. Shigoka M, Tsuchida A, Matsudo T, Nagakawa $Y$, Saito H, Suzuki Y, Aoki T, Murakami Y, Toyoda H, Kumada T et al: Deregulation of miR-92a expression is implicated in hepatocellular carcinoma development. Pathol Int 2010, 60(5):351-357.

44. Mitchell PS, Parkin RK, Kroh EM, Fritz BR, Wyman SK, Pogosova-Agadjanyan EL, Peterson A, Noteboom J, O'Briant KC, Allen A et al: Circulating microRNAs as stable blood-based markers for cancer detection. Proc Natl Acad Sci U S A 2008, 105(30):10513-10518

45. Skog J, Wurdinger $\mathrm{T}$, van Rijn S, Meijer DH, Gainche L, Sena-Esteves M, Curry WT, Jr., Carter BS, Krichevsky AM, Breakefield XO: Glioblastoma microvesicles transport RNA and proteins that promote tumour growth and provide diagnostic biomarkers. Nat Cell Biol 2008, 10(12):1470-1476.

46. Valadi H, Ekstrom K, Bossios A, Sjostrand M, Lee JJ, Lotvall JO: Exosome-mediated transfer of mRNAs and microRNAs is a novel mechanism of genetic exchange between cells. Nat Cell Biol 2007, 9(6):654-659. 
47. Kosaka N, Iguchi H, Yoshioka Y, Takeshita F, Matsuki Y, Ochiya T: Secretory mechanisms and intercellular transfer of microRNAs in living cells. J Biol Chem 2010, 285(23):17442-17452.

48. Pigati L, Yaddanapudi SC, Iyengar R, Kim DJ, Hearn SA, Danforth D, Hastings ML, Duelli DM: Selective release of microRNA species from normal and malignant mammary epithelial cells. PLoS One 2010, 5(10):e13515

49. Taylor DD, Gercel-Taylor C: MicroRNA signatures of tumor-derived exosomes as diagnostic biomarkers of ovarian cancer. Gynecol Oncol 2008, 110(1):13-21.

50. Hunter MP, Ismail N, Zhang X, Aguda BD, Lee EJ, Yu L, Xiao T, Schafer J, Lee ML, Schmittgen TD et al: Detection of microRNA expression in human peripheral blood microvesicles. PLoS One 2008, 3(11):e3694.

51. Rabinowits G, Gercel-Taylor C, Day JM, Taylor DD, Kloecker GH: Exosomal microRNA: a diagnostic marker for lung cancer. Clin Lung Cancer 2009, 10(1):42-46.

52. Valadi H, Ekström K, Bossios A, Sjöstrand M, Lee JJ, Lötvall JO: Exosome-mediated transfer of mRNAs and microRNAs is a novel mechanism of genetic exchange between cells. Nat Cell Biol 2007, 9(6):654-659.

53. Pan BT, Johnstone RM: Fate of the transferrin receptor during maturation of sheep reticulocytes in vitro: selective externalization of the receptor. Cell 1983, 33(3):967-978.

54. Théry C, Regnault A, Garin J, Wolfers J, Zitvogel L, Ricciardi-Castagnoli P, Raposo G, Amigorena S: Molecular characterization of dendritic cell-derived exosomes. Selective accumulation of the heat shock protein hsc73. J Cell Biol 1999, 147(3):599-610.

55. Raposo G, Nijman HW, Stoorvogel W, Liejendekker R, Harding CV, Melief CJ, Geuze HJ: B lymphocytes secrete antigen-presenting vesicles. J Exp Med 1996, 183(3):1161-1172.

56. Blanchard N, Lankar D, Faure F, Regnault A, Dumont C, Raposo G, Hivroz C: TCR activation of human T cells induces the production of exosomes bearing the TCR/CD3/zeta complex. J Immunol 2002, 168(7):3235-3241.

57. Raposo G, Tenza D, Mecheri S, Peronet R, Bonnerot C, Desaymard C: Accumulation of major histocompatibility complex class II molecules in mast cell secretory granules and their release upon degranulation. Mol Biol Cell 1997, 8(12):2631-2645.

58. van Niel G, Raposo G, Candalh C, Boussac M, Hershberg R, Cerf-Bensussan N, Heyman M: Intestinal epithelial cells secrete exosome-like vesicles. Gastroenterology 2001, 121(2):337-349.

59. Mears R, Craven RA, Hanrahan S, Totty N, Upton C, Young SL, Patel P, Selby PJ, Banks RE: Proteomic analysis of melanoma-derived exosomes by two-dimensional polyacrylamide gel electrophoresis and mass spectrometry. Proteomics 2004, 4(12):4019-4031.

60. Kosaka N, Iguchi H, Yoshioka Y, Takeshita F, Matsuki Y, Ochiya T: Secretory mechanisms and intercellular transfer of microRNAs in living cells. J Biol Chem 2010, 285(23):17442-17452.

61. Brase JC, Wuttig D, Kuner R, Sültmann H: Serum microRNAs as non-invasive biomarkers for cancer. Mol Cancer 2010, 9:306.

62. Taylor DD, Homesley HD, Doellgast GJ: Binding of specific peroxidase-labeled antibody to placental-type phosphatase on tumor-derived membrane fragments. Cancer Res 1980, 40(11):4064-4069.

63. Taylor DD, Gercel-Taylor C: MicroRNA signatures of tumor-derived exosomes as diagnostic biomarkers of ovarian cancer. Gynecol Oncol 2008, 110(1):13-21.

64. Rupp AK, Rupp C, Keller S, Brase JC, Ehehalt R, Fogel M, Moldenhauer G, Marme F, Sultmann H, Altevogt P: Loss of EpCAM expression in breast cancer derived serum exosomes: role of proteolytic cleavage. Gynecol Oncol 2011, 122(2):437-446.

65. Rabinowits G, Gerçel-Taylor C, Day JM, Taylor DD, Kloecker GH: Exosomal microRNA: a diagnostic marker for lung cancer. Clin Lung Cancer 2009, 10(1):42-46.

66. Vickers KC, Palmisano BT, Shoucri BM, Shamburek RD, Remaley AT: MicroRNAs are transported in plasma and delivered to recipient cells by high-density lipoproteins. Nat Cell Biol 2011, 13(4):423-433.
67. Rottiers V, Naar AM: MicroRNAs in metabolism and metabolic disorders. Nat Rev Mol Cell Biol 2012, 13(4):239-250.

68. Morelli AE, Larregina AT, Shufesky WJ, Sullivan ML, Stolz DB, Papworth GD, Zahorchak AF, Logar AJ, Wang Z, Watkins SC et al: Endocytosis, intracellular sorting, and processing of exosomes by dendritic cells. Blood 2004, 104(10):3257-3266.

69. Tian T, Wang Y, Wang H, Zhu Z, Xiao Z: Visualizing of the cellular uptake and intracellular trafficking of exosomes by live-cell microscopy. J Cell Biochem 2010, 111(2):488-496.

70. Montecalvo A, Larregina AT, Shufesky WJ, Stolz DB, Sullivan ML, Karlsson JM, Baty CJ, Gibson GA, Erdos G, Wang Z et al: Mechanism of transfer of functional microRNAs between mouse dendritic cells via exosomes. Blood 2012, 119(3):756-766.

71. Parolini I, Federici C, Raggi C, Lugini L, Palleschi S, De Milito A, Coscia C, Iessi E, Logozzi M, Molinari A et al: Microenvironmental $\mathrm{pH}$ is a key factor for exosome traffic in tumor cells. J Biol Chem 2009, 284(49):34211-34222

72. Turchinovich A, Weiz L, Langheinz A, Burwinkel B: Characterization of extracellular circulating microRNA. Nucleic Acids Res 2011, 39(16):7223-7233.

73. Gilad S, Meiri E, Yogev Y, Benjamin S, Lebanony D, Yerushalmi N, Benjamin H, Kushnir M, Cholakh H, Melamed N et al: Serum microRNAs are promising novel biomarkers. PLoS One 2008, 3(9):e3148.

74. Roth C, Rack B, Muller V, Janni W, Pantel K, Schwarzenbach H: Circulating microRNAs as blood-based markers for patients with primary and metastatic breast cancer. Breast Cancer Res, 2010;12(6):R90.

75. Liu R, Zhang C, Hu Z, Li G, Wang C, Yang C, Huang D, Chen X, Zhang $\mathrm{H}$, Zhuang $\mathrm{R}$ et al: A five-microRNA signature identified from genome-wide serum microRNA expression profiling serves as a fingerprint for gastric cancer diagnosis. Eur J Cancer 2011, 47(5):784-791.

76. Hu Z, Chen X, Zhao Y, Tian T, Jin G, Shu Y, Chen Y, Xu L, Zen K, Zhang $C$ et al: Serum microRNA signatures identified in a genome-wide serum microRNA expression profiling predict survival of non-small-cell lung cancer. J Clin Oncol 2010, 28(10):1721-1726.

77. Nasser MW, Datta J, Nuovo G, Kutay H, Motiwala T, Majumder S, Wang B, Suster S, Jacob ST, Ghoshal K: Down-regulation of micro-RNA-1 (miR-1) in lung cancer. Suppression of tumorigenic property of lung cancer cells and their sensitization to doxorubicin-induced apoptosis by miR-1. J Biol Chem 2008, 283(48):33394-33405.

78. Datta J, Kutay H, Nasser MW, Nuovo GJ, Wang B, Majumder S, Liu CG, Volinia S, Croce CM, Schmittgen TD et al: Methylation mediated silencing of MicroRNA-1 gene and its role in hepatocellular carcinogenesis. Cancer Res 2008, 68(13):5049-5058.

79. Yan D, Dong Xda E, Chen X, Wang L, Lu C, Wang J, Qu J, Tu L: MicroRNA-1/206 targets c-Met and inhibits rhabdomyosarcoma development. J Biol Chem 2009, 284(43):29596-29604.

80. Nohata N, Sone Y, Hanazawa T, Fuse M, Kikkawa N, Yoshino H, Chiyomaru T, Kawakami K, Enokida H, Nakagawa M et al: miR-1 as a tumor suppressive microRNA targeting TAGLN2 in head and neck squamous cell carcinoma. Oncotarget 2011, 2(1-2):29-42.

81. Yoshino H, Chiyomaru T, Enokida H, Kawakami K, Tatarano S, Nishiyama K, Nohata N, Seki N, Nakagawa M: The tumour-suppressive function of miR-1 and miR-133a targeting TAGLN2 in bladder cancer. Br I Cancer 2011, 104(5):808-818.

82. Heneghan HM, Miller N, Kelly R, Newell J, Kerin MJ: Systemic miRNA-195 differentiates breast cancer from other malignancies and is a potential biomarker for detecting noninvasive and early stage disease. Oncologist 2010, 15(7):673-682.

83. Moriarty $\mathrm{CH}$, Pursell B, Mercurio AM: miR-10b targets Tiam1: implications for Rac activation and carcinoma migration. J Biol Chem 2010, 285(27):20541-20546.

84. Ma L, Teruya-Feldstein J, Weinberg RA: Tumour invasion and metastasis initiated by microRNA-10b in breast cancer. Nature 2007, 449(7163):682-688.

85. Ma L, Reinhardt F, Pan E, Soutschek J, Bhat B, Marcusson EG, Teruya-Feldstein J, Bell GW, Weinberg RA: Therapeutic silencing of 
miR-10b inhibits metastasis in a mouse mammary tumor model. Nat Biotechnol 2010, 28(4):341-347.

86. Hui AB, Shi W, Boutros PC, Miller N, Pintilie M, Fyles T, McCready D, Wong D, Gerster K, Waldron L et al: Robust global micro-RNA profiling with formalin-fixed paraffin-embedded breast cancer tissues. Lab Invest 2009, 89(5):597-606.

87. Heegaard NH, Schetter AJ, Welsh JA, Yoneda M, Bowman ED, Harris CC: Circulating microRNA expression profiles in early stage non-small cell lung cancer. Int J Cancer 2012, 130(6):1378-1386.

88. Moussay E, Wang K, Cho JH, van Moer K, Pierson S, Paggetti J, Nazarov PV, Palissot V, Hood LE, Berchem G et al: MicroRNA as biomarkers and regulators in B-cell chronic lymphocytic leukemia. Proc Natl Acad Sci U S A 2011, 108(16):6573-6578.

89. Petrocca F, Visone R, Onelli MR, Shah MH, Nicoloso MS, de Martino I, Iliopoulos D, Pilozzi E, Liu CG, Negrini M et al: E2F1-regulated microRNAs impair TGFbeta-dependent cell-cycle arrest and apoptosis in gastric cancer. Cancer Cell 2008, 13(3):272-286.

90. Li T, Li D, Sha J, Sun P, Huang Y: MicroRNA-21 directly targets MARCKS and promotes apoptosis resistance and invasion in prostate cancer cells. Biochem Biophys Res Commun 2009, 383(3):280-285.

91. Schramedei K, Morbt N, Pfeifer G, Lauter J, Rosolowski M, Tomm JM, von Bergen M, Horn F, Brocke-Heidrich K: MicroRNA-21 targets tumor suppressor genes ANP32A and SMARCA4. Oncogene 2011, 30(26):2975-2985.

92. Qin W, Zhao B, Shi Y, Yao C, Jin L, Jin Y: BMPRII is a direct target of miR-21. Acta Biochim Biophys Sin (Shanghai) 2009, 41(7):618-623.

93. Meng F, Henson R, Wehbe-Janek H, Ghoshal K, Jacob ST, Patel T: MicroRNA-21 regulates expression of the PTEN tumor suppressor gene in human hepatocellular cancer. Gastroenterology 2007, 133(2):647-658.

94. Yan LX, Wu QN, Zhang Y, Li YY, Liao DZ, Hou JH, Fu J, Zeng MS, Yun JP, Wu QL et al: Knockdown of miR-21 in human breast cancer cell lines inhibits proliferation, in vitro migration and in vivo tumor growth. Breast Cancer Res 2011, 13(1):R2.

95. Frankel LB, Christoffersen NR, Jacobsen A, Lindow M, Krogh A, Lund AH: Programmed cell death 4 (PDCD4) is an important functional target of the microRNA miR-21 in breast cancer cells. $J$ Biol Chem 2008, 283(2):1026-1033.

96. Lu Z, Liu M, Stribinskis V, Klinge CM, Ramos KS, Colburn NH, Li Y: MicroRNA-21 promotes cell transformation by targeting the programmed cell death 4 gene. Oncogene 2008, 27(31):4373-4379.

97. Zhu S, Si ML, Wu H, Mo YY: MicroRNA-21 targets the tumor suppressor gene tropomyosin 1 (TPM1). J Biol Chem 2007, 282(19):14328-14336.

98. Yu Y, Wang Y, Ren X, Tsuyada A, Li A, Liu LJ, Wang SE: Context-dependent bidirectional regulation of the MutS homolog 2 by transforming growth factor beta contributes to chemoresistance in breast cancer cells. Mol Cancer Res 2010, 8(12):1633-1642.

99. Song B, Wang C, Liu J, Wang X, Lv L, Wei L, Xie L, Zheng Y, Song $\mathrm{X}$ : MicroRNA-21 regulates breast cancer invasion partly by targeting tissue inhibitor of metalloproteinase 3 expression. J Exp Clin Cancer Res 2010, 29:29.

100. Wickramasinghe NS, Manavalan TT, Dougherty SM, Riggs KA, Li Y, Klinge CM: Estradiol downregulates miR-21 expression and increases miR-21 target gene expression in MCF-7 breast cancer cells. Nucleic Acids Res 2009, 37(8):2584-2595.

101. Xu J, Wu C, Che X, Wang L, Yu D, Zhang T, Huang L, Li H, Tan W, Wang $C$ et al: Circulating microRNAs, miR-21, miR-122, and miR-223, in patients with hepatocellular carcinoma or chronic hepatitis. Mol Carcinog 2011, 50(2):136-142.

102. Connolly EC, Van Doorslaer K, Rogler LE, Rogler CE: Overexpression of miR-21 promotes an in vitro metastatic phenotype by targeting the tumor suppressor RHOB. Mol Cancer Res 2010, 8(5):691-700.

103. Lawrie $\mathrm{CH}$, Soneji S, Marafioti $\mathrm{T}$, Cooper $\mathrm{CD}$, Palazzo S, Paterson JC, Cattan H, Enver T, Mager R, Boultwood J et al: MicroRNA expression distinguishes between germinal center $\mathrm{B}$ cell-like and activated B cell-like subtypes of diffuse large B cell lymphoma. Int J Cancer 2007, 121(5):1156-1161.
104. Lawrie CH, Gal S, Dunlop HM, Pushkaran B, Liggins AP, Pulford K, Banham AH, Pezzella F, Boultwood J, Wainscoat JS et al: Detection of elevated levels of tumour-associated microRNAs in serum of patients with diffuse large B-cell lymphoma. $\mathrm{Br} J$ Haematol 2008, 141(5):672-675.

105. Baraniskin A, Kuhnhenn J, Schlegel U, Chan A, Deckert M, Gold R, Maghnouj A, Zollner H, Reinacher-Schick A, Schmiegel W et al: Identification of microRNAs in the cerebrospinal fluid as marker for primary diffuse large B-cell lymphoma of the central nervous system. Blood 2011, 117(11):3140-3146.

106. Zhang HL, Yang LF, Zhu Y, Yao XD, Zhang SL, Dai B, Zhu YP, Shen YJ, Shi GH, Ye DW: Serum miRNA-21: elevated levels in patients with metastatic hormone-refractory prostate cancer and potential predictive factor for the efficacy of docetaxel-based chemotherapy. Prostate 2011, 71(3):326-331.

107. Yaman Agaoglu F, Kovancilar M, Dizdar Y, Darendeliler E, Holdenrieder S, Dalay N, Gezer U: Investigation of miR-21, miR-141, and miR-221 in blood circulation of patients with prostate cancer. Tumour Biol 2011, 32(3):583-588.

108. Kong X, Du Y, Wang G, Gao J, Gong Y, Li L, Zhang Z, Zhu J, Jing Q, Qin $Y$ et al: Detection of differentially expressed microRNAs in serum of pancreatic ductal adenocarcinoma patients: miR-196a could be a potential marker for poor prognosis. Dig Dis Sci 2011, 56(2):602-609.

109. Dong J, Zhao YP, Zhou L, Zhang TP, Chen G: Bcl-2 Upregulation Induced by miR-21 Via a Direct Interaction Is Associated with Apoptosis and Chemoresistance in MIA PaCa-2 Pancreatic Cancer Cells. Arch Med Res 2011, 42(1):8-14.

110. Habbe N, Koorstra JB, Mendell JT, Offerhaus GJ, Ryu JK, Feldmann G, Mullendore ME, Goggins MG, Hong SM, Maitra A: MicroRNA miR-155 is a biomarker of early pancreatic neoplasia. Cancer Biol Ther 2009, 8(4):340-346.

111. Ryu JK, Hong SM, Karikari CA, Hruban RH, Goggins MG, Maitra A: Aberrant MicroRNA-155 expression is an early event in the multistep progression of pancreatic adenocarcinoma. Pancreatology 2010, 10(1):66-73.

112. Wei J, Gao W, Zhu CJ, Liu YQ, Mei Z, Cheng T, Shu YQ: Identification of plasma microRNA-21 as a biomarker for early detection and chemosensitivity of non-small cell lung cancer. Chin J Cancer 2011, 30(6):407-414.

113. Lee JH, Voortman J, Dingemans AM, Voeller DM, Pham T, Wang Y, Giaccone G: MicroRNA Expression and Clinical Outcome of Small Cell Lung Cancer. PLoS One 2011, 6(6):e21300.

114. Zhang Z, Li Z, Gao C, Chen P, Chen J, Liu W, Xiao S, Lu H: miR-21 plays a pivotal role in gastric cancer pathogenesis and progression. Lab Invest 2008, 88(12):1358-1366.

115. Wang F, Zheng Z, Guo J, Ding X: Correlation and quantitation of microRNA aberrant expression in tissues and sera from patients with breast tumor. Gynecol Oncol 2010, 119(3):586-593.

116. Asaga S, Kuo C, Nguyen T, Terpenning M, Giuliano AE, Hoon DS: Direct serum assay for microRNA-21 concentrations in early and advanced breast cancer. Clin Chem 2011, 57(1):84-91.

117. Zhu S, Wu H, Wu F, Nie D, Sheng S, Mo YY: MicroRNA-21 targets tumor suppressor genes in invasion and metastasis. Cell Res 2008, 18(3):350-359.

118. Gong C, Yao Y, Wang Y, Liu B, Wu W, Chen J, Su F, Yao H, Song E: Upregulation of MIR-21 mediates resistance to trastuzumab therapy for breast cancer. J Biol Chem 2011, 286(21):19127-19137.

119. Terao M, Fratelli M, Kurosaki M, Zanetti A, Guarnaccia V, Paroni G, Tsykin A, Lupi M, Gianni M, Goodall GJ et al: Induction of miR-21 by retinoic acid in estrogen receptor-positive breast carcinoma cells: biological correlates and molecular targets. J Biol Chem 2011, 286(5):4027-4042.

120. Lin SC, Liu CJ, Lin JA, Chiang WF, Hung PS, Chang KW: miR-24 up-regulation in oral carcinoma: positive association from clinical and in vitro analysis. Oral Oncol 2010, 46(3):204-208.

121. Liu X, Wang A, Heidbreder CE, Jiang L, Yu J, Kolokythas A, Huang L, Dai Y, Zhou X: MicroRNA-24 targeting RNA-binding protein DND1 in tongue squamous cell carcinoma. FEBS Lett 2010, 584(18):4115-4120.

122. Resnick KE, Alder H, Hagan JP, Richardson DL, Croce CM, Cohn DE: The detection of differentially expressed microRNAs from the 
serum of ovarian cancer patients using a novel real-time PCR platform. Gynecol Oncol 2009, 112(1):55-59.

123. Kim DH, Pickhardt PJ, Taylor AJ, Leung WK, Winter TC, Hinshaw JL, Gopal DV, Reichelderfer M, Hsu RH, Pfau PR: CT colonography versus colonoscopy for the detection of advanced neoplasia. $N$ Engl J Med 2007, 357(14):1403-1412.

124. Kim DH, Pickhardt PJ, Taylor AJ: Characteristics of advanced adenomas detected at CT colonographic screening: implications for appropriate polyp size thresholds for polypectomy versus surveillance. AJR Am J Roentgenol 2007, 188(4):940-944.

125. Winawer SJ, Zauber AG: The advanced adenoma as the primary target of screening. Gastrointest Endosc Clin N Am 2002, 12(1):1-9.

126. Tanaka M, Oikawa K, Takanashi M, Kudo M, Ohyashiki J, Ohyashiki K, Kuroda M: Down-regulation of miR-92 in human plasma is a novel marker for acute leukemia patients. PLoS One 2009, 4(5):e5532.

127. Ohyashiki JH, Umezu T, Kobayashi C, Hamamura RS, Tanaka M, Kuroda M, Ohyashiki K: Impact on cell to plasma ratio of miR-92a in patients with acute leukemia: in vivo assessment of cell to plasma ratio of miR-92a. BMC Res Notes 2010, 3:347.

128. Lin CJ, Gong HY, Tseng HC, Wang WL, Wu JL: miR-122 targets an anti-apoptotic gene, Bcl-w, in human hepatocellular carcinoma cell lines. Biochem Biophys Res Commun 2008, 375(3):315-320.

129. Ma L, Liu J, Shen J, Liu L, Wu J, Li W, Luo J, Chen Q, Qian C: Expression of miR-122 mediated by adenoviral vector induces apoptosis and cell cycle arrest of cancer cells. Cancer Biol Ther 2010, 9(7):554-561.

130. Gramantieri L, Ferracin M, Fornari F, Veronese A, Sabbioni S, Liu CG, Calin GA, Giovannini C, Ferrazzi E, Grazi GL et al: Cyclin G1 is a target of miR-122a, a microRNA frequently down-regulated in human hepatocellular carcinoma. Cancer Res 2007, 67(13):6092-6099.

131. Fornari F, Gramantieri L, Giovannini C, Veronese A, Ferracin M, Sabbioni S, Calin GA, Grazi GL, Croce CM, Tavolari S et al: MiR-122/cyclin G1 interaction modulates p53 activity and affects doxorubicin sensitivity of human hepatocarcinoma cells. Cancer Res 2009, 69(14):5761-5767.

132. Tsai WC, Hsu PW, Lai TC, Chau GY, Lin CW, Chen CM, Lin CD, Liao YL, Wang JL, Chau YP et al: MicroRNA-122, a tumor suppressor microRNA that regulates intrahepatic metastasis of hepatocellular carcinoma. Hepatology 2009, 49(5):1571-1582.

133. Bai S, Nasser MW, Wang B, Hsu SH, Datta J, Kutay H, Yadav A, Nuovo G, Kumar P, Ghoshal K: MicroRNA-122 inhibits tumorigenic properties of hepatocellular carcinoma cells and sensitizes these cells to sorafenib. J Biol Chem 2009, 284(46):32015-32027.

134. Coulouarn C, Factor VM, Andersen JB, Durkin ME, Thorgeirsson SS: Loss of miR-122 expression in liver cancer correlates with suppression of the hepatic phenotype and gain of metastatic properties. Oncogene 2009, 28(40):3526-3536.

135. Cheng H, Zhang L, Cogdell DE, Zheng H, Schetter AJ, Nykter M, Harris CC, Chen K, Hamilton SR, Zhang W: Circulating plasma MiR-141 is a novel biomarker for metastatic colon cancer and predicts poor prognosis. PLoS One 2011, 6(3):e17745.

136. Hu M, Xia M, Chen X, Lin Z, Xu Y, Ma Y, Su L: MicroRNA-141 regulates Smad interacting protein 1 (SIP1) and inhibits migration and invasion of colorectal cancer cells. Dig Dis Sci 2010, 55(8):2365-2372

137. Vandewalle C, Comijn J, De Craene B, Vermassen P, Bruyneel E, Andersen H, Tulchinsky E, Van Roy F, Berx G: SIP1/ZEB2 induces EMT by repressing genes of different epithelial cell-cell junctions. Nucleic Acids Res 2005, 33(20):6566-6578.

138. Acun T, Oztas E, Yagci T, Yakicier MC: SIP1 is Downregulated in Hepatocellular Carcinoma by Promoter Hypermethylation. BMC Cancer 2011, 11(1):223.

139. Brase JC, Johannes M, Schlomm T, Fälth M, Haese A, Steuber T, Beissbarth $\mathrm{T}$, Kuner R, Sültmann H: Circulating miRNAs are correlated with tumor progression in prostate cancer. Int I Cancer 2011, 128(3):608-616.

140. Faraoni I, Antonetti FR, Cardone J, Bonmassar E: miR-155 gene: a typical multifunctional microRNA. Biochim Biophys Acta 2009, 1792(6):497-505.
141. Wang J, Chen J, Chang P, LeBlanc A, Li D, Abbruzzesse JL, Frazier ML, Killary AM, Sen S: MicroRNAs in plasma of pancreatic ductal adenocarcinoma patients as novel blood-based biomarkers of disease. Cancer Prev Res (Phila) 2009, 2(9):807-813.

142. Gironella M, Seux M, Xie MJ, Cano C, Tomasini R, Gommeaux J, Garcia S, Nowak J, Yeung ML, Jeang KT et al: Tumor protein 53-induced nuclear protein 1 expression is repressed by miR-155, and its restoration inhibits pancreatic tumor development. Proc Natl Acad Sci U S A 2007, 104(41):16170-16175.

143. Greither T, Grochola LF, Udelnow A, Lautenschläger C, Würl P, Taubert H: Elevated expression of microRNAs 155, 203, 210 and 222 in pancreatic tumors is associated with poorer survival. Int J Cancer 2010, 126(1):73-80.

144. Lawrie CH, Soneji S, Marafioti T, Cooper CD, Palazzo S, Paterson JC, Cattan H, Enver T, Mager R, Boultwood J et al: MicroRNA expression distinguishes between germinal center $\mathrm{B}$ cell-like and activated B cell-like subtypes of diffuse large B cell lymphoma. Int J Cancer 2007, 121(5):1156-1161.

145. Rai D, Karanti S, Jung I, Dahia PL, Aguiar RC: Coordinated expression of microRNA-155 and predicted target genes in diffuse large B-cell lymphoma. Cancer Genet Cytogenet 2008, 181(1):8-15.

146. Pedersen IM, Otero D, Kao E, Miletic AV, Hother C, Ralfkiaer E, Rickert RC, Gronbaek K, David M: Onco-miR-155 targets SHIP1 to promote TNFalpha-dependent growth of B cell lymphomas. EMBO Mol Med 2009, 1(5):288-295.

147. Kluiver J, Poppema S, de Jong D, Blokzijl T, Harms G, Jacobs S, Kroesen BJ, van den Berg A: BIC and miR-155 are highly expressed in Hodgkin, primary mediastinal and diffuse large B cell lymphomas. J Pathol 2005, 207(2):243-249.

148. Gibcus JH, Tan LP, Harms G, Schakel RN, de Jong D, Blokzijl T, Möller P, Poppema S, Kroesen BJ, van den Berg A: Hodgkin lymphoma cell lines are characterized by a specific miRNA expression profile. Neoplasia 2009, 11(2):167-176.

149. Jiang S, Zhang HW, Lu MH, He XH, Li Y, Gu H, Liu MF, Wang ED: MicroRNA-155 functions as an OncomiR in breast cancer by targeting the suppressor of cytokine signaling 1 gene. Cancer Res 2010, 70(8):3119-3127.

150. Kong W, He L, Coppola M, Guo J, Esposito NN, Coppola D, Cheng JQ: MicroRNA-155 regulates cell survival, growth, and chemosensitivity by targeting FOXO3a in breast cancer. J Biol Chem 2010, 285(23):17869-17879.

151. Li D, Zhao Y, Liu C, Chen X, Qi Y, Jiang Y, Zou C, Zhang X, Liu S, Wang $X$ et al: Analysis of MiR-195 and MiR-497 expression, regulation and role in breast cancer. Clin Cancer Res 2011, 17(7):1722-1730.

152. Hannafon BN, Sebastiani P, de Las Morenas A, Lu J, Rosenberg CL: Expression of microRNA and their gene targets are dysregulated in preinvasive breast cancer. Breast Cancer Res 2011, 13(2):R24.

153. Liu L, Chen L, Xu Y, Li R, Du X: microRNA-195 promotes apoptosis and suppresses tumorigenicity of human colorectal cancer cells. Biochem Biophys Res Commun 2010, 400(2):236-240.

154. Xu T, Zhu Y, Xiong Y, Ge YY, Yun JP, Zhuang SM: MicroRNA-195 suppresses tumorigenicity and regulates G1/S transition of human hepatocellular carcinoma cells. Hepatology 2009, 50(1):113-121.

155. Mertens-Talcott SU, Chintharlapalli S, Li X, Safe S: The oncogenic microRNA-27a targets genes that regulate specificity protein transcription factors and the G2-M checkpoint in MDA-MB-231 breast cancer cells. Cancer Res 2007, 67(22):11001-11011.

156. Pu XX, Huang GL, Guo HQ, Guo CC, Li H, Ye S, Ling S, Jiang L, Tian Y, Lin TY: Circulating miR-221 directly amplified from plasma is a potential diagnostic and prognostic marker of colorectal cancer and is correlated with p53 expression. J Gastroenterol Hepatol 2010, 25(10):1674-1680.

157.Zheng C, Yinghao S, Li J: MiR-221 expression affects invasion potential of human prostate carcinoma cell lines by targeting DVL2. Med Oncol 2011, 29(2):815-822.

158. Chen Y, Zaman MS, Deng G, Majid S, Saini S, Liu J, Tanaka Y, Dahiya R: MicroRNAs 221/222 and genistein-mediated regulation of ARHI tumor suppressor gene in prostate cancer. Cancer Prev Res (Phila) 2011, 4(1):76-86.

159. Galardi S, Mercatelli N, Giorda E, Massalini S, Frajese GV, Ciafrè SA, Farace MG: miR-221 and miR-222 expression affects the 
proliferation potential of human prostate carcinoma cell lines by targeting p27Kip1. J Biol Chem 2007, 282(32):23716-23724.

160. Garofalo M, Di Leva G, Romano G, Nuovo G, Suh SS, Ngankeu A, Taccioli C, Pichiorri F, Alder H, Secchiero P et al: miR-221\&222 regulate TRAIL resistance and enhance tumorigenicity through PTEN and TIMP3 downregulation. Cancer Cell 2009, 16(6):498-509.

161. Wach S, Nolte E, Szczyrba J, Stöhr R, Hartmann A, Orntoft T, Dyrskjøt L, Eltze E, Wieland W, Keck B et al: MicroRNA profiles of prostate carcinoma detected by multiplatform microRNA screening. Int J Cancer 2012, 130(3):611-621.

162. Kroh EM, Parkin RK, Mitchell PS, Tewari M: Analysis of circulating microRNA biomarkers in plasma and serum using quantitative reverse transcription-PCR (qRT-PCR). Methods 2010, 50(4):298-301.

163. Fichtlscherer S, De Rosa S, Fox H, Schwietz T, Fischer A, Liebetrau C, Weber M, Hamm CW, Roxe T, Muller-Ardogan $M$ et al: Circulating microRNAs in patients with coronary artery disease. Circ Res 2010, 107(5):677-684.

164. Duttagupta R, Jiang R, Gollub J, Getts RC, Jones KW: Impact of cellular miRNAs on circulating miRNA biomarker signatures. PLoS One 2011, 6(6):e20769.

165. Rupp AK, Rupp C, Keller S, Brase JC, Ehehalt R, Fogel M, Moldenhauer G, Marme F, Sultmann H, Altevogt P: Loss of EpCAM expression in breast cancer derived serum exosomes: role of proteolytic cleavage. Gynecol Oncol 2011, 122(2):437-446.

166. Pritchard CC, Kroh E, Wood B, Arroyo JD, Dougherty KJ, Miyaji $\mathrm{MM}$, Tait JF, Tewari M: Blood cell origin of circulating microRNAs: a cautionary note for cancer biomarker studies. Cancer Prev Res (Phila) 2012, 5(3):492-497.

167.Zubakov D, Boersma AW, Choi Y, van Kuijk PF, Wiemer EA, Kayser M: MicroRNA markers for forensic body fluid identification obtained from microarray screening and quantitative RT-PCR confirmation. Int J Legal Med 2010, 124(3):217-226.

168. Kosaka N, Iguchi H, Ochiya T: Circulating microRNA in body fluid: a new potential biomarker for cancer diagnosis and prognosis. Cancer Sci 2010, 101(10):2087-2092.

169. Frankel LB, Christoffersen NR, Jacobsen A, Lindow M, Krogh A, Lund AH: Programmed cell death 4 (PDCD4) is an important functional target of the microRNA miR-21 in breast cancer cells. $J$ Biol Chem 2008, 283(2):1026-1033.

170. Lu Z, Liu M, Stribinskis V, Klinge CM, Ramos KS, Colburn NH, Li Y: MicroRNA-21 promotes cell transformation by targeting the programmed cell death 4 gene. Oncogene 2008, 27(31):4373-4379.

171. Yang Y, Chaerkady R, Beer MA, Mendell JT, Pandey A: Identification of miR-21 targets in breast cancer cells using a quantitative proteomic approach. Proteomics 2009, 9(5):1374-1384

172. Mudduluru G, Ceppi P, Kumarswamy R, Scagliotti GV, Papotti M, Allgayer H: Regulation of Axl receptor tyrosine kinase expression by miR-34a and miR-199a/b in solid cancer. Oncogene 2011, 30(25):2888-2899.

173. Zhang J, Du YY, Lin YF, Chen YT, Yang L, Wang HJ, Ma D: The cell growth suppressor, mir-126, targets IRS-1. Biochem Biophys Res Commun 2008, 377(1):136-140.

174. Ng EK, Chong WW, Jin H, Lam EK, Shin VY, Yu J, Poon TC, Ng SS, Sung JJ: Differential expression of microRNAs in plasma of patients with colorectal cancer: a potential marker for colorectal cancer screening. Gut 2009, 58(10):1375-1381.

175. Rai D, Kim SW, McKeller MR, Dahia PL, Aguiar RC: Targeting of SMAD5 links microRNA-155 to the TGF-beta pathway and lymphomagenesis. Proc Natl Acad Sci U S A 2010, 107(7):3111-3116.

176. Gibcus JH, Tan LP, Harms G, Schakel RN, de Jong D, Blokzijl T, Moller P, Poppema S, Kroesen BJ, van den Berg A: Hodgkin lymphoma cell lines are characterized by a specific miRNA expression profile. Neoplasia 2009, 11(2):167-176.

177. Zhang C, Wang C, Chen X, Yang C, Li K, Wang J, Dai J, Hu Z, Zhou $X$, Chen L et al: Expression profile of microRNAs in serum: a fingerprint for esophageal squamous cell carcinoma. Clin Chem 2010, 56(12):1871-1879.

178. Yang Q, Jie Z, Cao H, Greenlee AR, Yang C, Zou F, Jiang Y: Low-level expression of let-7a in gastric cancer and its involvement in tumorigenesis by targeting RAB40C. Carcinogenesis 2011, 32(5):713-722.
179. Liu R, Zhang C, Hu Z, Li G, Wang C, Yang C, Huang D, Chen X, Zhang $\mathrm{H}$, Zhuang $\mathrm{R}$ et al: A five-microRNA signature identified from genome-wide serum microRNA expression profiling serves as a fingerprint for gastric cancer diagnosis. Eur I Cancer 2011, 47(5):784-791.

180. Liu T, Tang H, Lang Y, Liu M, Li X: MicroRNA-27a functions as an oncogene in gastric adenocarcinoma by targeting prohibitin. Cancer Lett 2009, 273(2):233-242.

181. Wong QW, Lung RW, Law PT, Lai PB, Chan KY, To KF, Wong N: MicroRNA-223 is commonly repressed in hepatocellular carcinoma and potentiates expression of Stathmin1. Gastroenterology 2008, 135(1):257-269.

182. Xu H, He JH, Xiao ZD, Zhang QQ, Chen YQ, Zhou H, Qu LH: Liver-enriched transcription factors regulate microRNA-122 that targets CUTL1 during liver development. Hepatology 2010, 52(4):1431-1442.

183. Yamamoto Y, Kosaka N, Tanaka M, Koizumi F, Kanai Y, Mizutani T, Murakami Y, Kuroda M, Miyajima A, Kato T et al: MicroRNA-500 as a potential diagnostic marker for hepatocellular carcinoma. Biomarkers 2009, 14(7):529-538.

184. Gui J, Tian $Y$, Wen X, Zhang W, Zhang P, Gao J, Run W, Tian L, Jia X, Gao Y: Serum microRNA characterization identifies miR-885-5p as a potential marker for detecting liver pathologies. Clin Sci (Lond) 2011, 120(5):183-193.

185. Silva J, Garcia V, Zaballos A, Provencio M, Lombardia L, Almonacid L, Garcia JM, Dominguez G, Pena C, Diaz R et al: Vesicle-related microRNAs in plasma of nonsmall cell lung cancer patients and correlation with survival. Eur Respir J 2011, 37(3):617-623.

186. Zhang JG, Wang JJ, Zhao F, Liu Q, Jiang K, Yang GH: MicroRNA-21 (miR-21) represses tumor suppressor PTEN and promotes growth and invasion in non-small cell lung cancer (NSCLC). Clin Chim Acta 2010, 411(11-12):846-852.

187. Hu Z, Chen X, Zhao Y, Tian T, Jin G, Shu Y, Chen Y, Xu L, Zen K, Zhang $C$ et al: Serum microRNA signatures identified in a genome-wide serum microRNA expression profiling predict survival of non-small-cell lung cancer. J Clin Oncol 2010, 28(10):1721-1726.

188. Jeong HC, Kim EK, Lee JH, Lee JM, Yoo HN, Kim JK: Aberrant expression of let-7a miRNA in the blood of non-small cell lung cancer patients. Mol Med Report 2011, 4(2):383-387.

189. He X, Duan C, Chen J, Ou-Yang X, Zhang Z, Li C, Peng H: Let-7a elevates p21(WAF1) levels by targeting of NIRF and suppresses the growth of A549 lung cancer cells. FEBS Lett 2009, 583(21):3501-3507.

190. Miller TE, Ghoshal K, Ramaswamy B, Roy S, Datta J, Shapiro CL, Jacob S, Majumder S: MicroRNA-221/222 confers tamoxifen resistance in breast cancer by targeting p27Kip1. J Biol Chem 2008, 283(44):29897-29903.

191. Li A, Omura N, Hong SM, Vincent A, Walter K, Griffith M, Borges M, Goggins M: Pancreatic cancers epigenetically silence SIP1 and hypomethylate and overexpress miR-200a/200b in association with elevated circulating miR-200a and miR-200b levels. Cancer Res 2010, 70(13):5226-5237.

192. Brase JC, Johannes M, Schlomm T, Falth M, Haese A, Steuber T, Beissbarth $\mathrm{T}$, Kuner R, Sultmann H: Circulating miRNAs are correlated with tumor progression in prostate cancer. Int J Cancer 2011, 128(3):608-616.

193.Szczyrba J, Nolte E, Wach S, Kremmer E, Stöhr R, Hartmann A, Wieland W, Wullich B, Grässer FA: Downregulation of Sec23A Protein by miRNA-375 in Prostate Carcinoma. Mol Cancer Res 2011, 9(6):791-800.

194. Miyachi M, Tsuchiya K, Yoshida H, Yagyu S, Kikuchi K, Misawa A, Iehara T, Hosoi H: Circulating muscle-specific microRNA, miR-206, as a potential diagnostic marker for rhabdomyosarcoma. Biochem Biophys Res Commun 2010, 400(1):89-93.

195. Wong TS, Liu XB, Wong BY, Ng RW, Yuen AP, Wei WI: Mature miR-184 as Potential Oncogenic microRNA of Squamous Cell Carcinoma of Tongue. Clin Cancer Res 2008, 14(9):2588-2592. 